\title{
Destruction and reinstatement of coastal hypoxia in the South China Sea off the Pearl River estuary
}

\author{
Yangyang Zhao ${ }^{1,2}$, Khanittha Uthaipan ${ }^{1}$, Zhongming Lu$^{3}$, Yan Li $^{1}$, Jing Liu ${ }^{1}$, Hongbin Liu ${ }^{4,5}$, Jianping Gan ${ }^{3,5,6}$, \\ Feifei Meng ${ }^{1}$, and Minhan Dai ${ }^{1}$ \\ ${ }^{1}$ State Key Laboratory of Marine Environmental Science, College of Ocean and Earth Sciences, \\ Xiamen University, Xiamen, 361102, China \\ ${ }^{2}$ Environmental Physics, Institute of Biogeochemistry and Pollutant Dynamics, ETH Zurich, 8092 Zurich, Switzerland \\ ${ }^{3}$ Division of Environment and Sustainability, The Hong Kong University of Science and Technology, \\ Kowloon, Hong Kong SAR, China \\ ${ }^{4}$ Division of Life Science, The Hong Kong University of Science and Technology, Kowloon, Hong Kong SAR, China \\ ${ }^{5}$ Department of Ocean Science, The Hong Kong University of Science and Technology, Kowloon, Hong Kong SAR, China \\ ${ }^{6}$ Department of Mathematics, The Hong Kong University of Science and Technology, Kowloon, Hong Kong SAR, China
}

Correspondence: Minhan Dai (mdai@xmu.edu.cn)

Received: 22 September 2020 - Discussion started: 12 October 2020

Revised: 17 March 2021 - Accepted: 17 March 2021 - Published: 30 April 2021

\begin{abstract}
We examined the evolution of intermittent hypoxia off the Pearl River estuary based on three cruise legs conducted in July 2018: one during severe hypoxic conditions before the passage of a typhoon and two post-typhoon legs showing destruction of the hypoxia and its reinstatement. The lowest ever recorded regional dissolved oxygen (DO) concentration of $3.5 \mu \mathrm{mol} \mathrm{kg}{ }^{-1}\left(\sim 0.1 \mathrm{mg} \mathrm{L}^{-1}\right)$ was observed in bottom waters during leg 1 , with an $\sim 660 \mathrm{~km}^{2}$ area experiencing hypoxic conditions ( $\mathrm{DO}<63 \mu \mathrm{mol} \mathrm{kg}{ }^{-1}$ ). Hypoxia was completely destroyed by the typhoon passage but was quickly restored $\sim 6 \mathrm{~d}$ later, resulting primarily from high biochemical oxygen consumption in bottom waters that averaged $14.6 \pm 4.8 \mu \mathrm{mol} \mathrm{O}_{2} \mathrm{~kg}^{-1} \mathrm{~d}^{-1}$. The shoreward intrusion of offshore subsurface waters contributed to an additional $8.6 \pm 1.7 \%$ of oxygen loss during the reinstatement of hypoxia. Freshwater inputs suppressed wind-driven turbulent mixing, stabilizing the water column and facilitating the hypoxia formation. The rapid reinstatement of summer hypoxia has a shorter timescale than the water residence time, which is however comparable with that of its initial disturbance from frequent tropical cyclones that occur throughout the wet season. This has important implications for better understanding the intermittent nature of hypoxia and predicting coastal hypoxia in a changing climate.
\end{abstract}

\section{Introduction}

Coastal hypoxia has been increasingly exacerbated near the mouths of large rivers as a consequence of anthropogenic nutrient inputs (Gilbert et al., 2010; Rabalais et al., 2014; Breitburg et al., 2018). The rise in the size, intensity and frequency of eutrophication-induced hypoxia exposes coastal oceans to a higher risk of elevated $\mathrm{N}_{2} \mathrm{O}$ and $\mathrm{CH}_{4}$ production; enhanced ocean acidification; and associated reductions in biodiversity, shifts in community structures, and negative impacts on food security and livelihoods (Diaz and Rosenberg, 2008; VaquerSunyer and Duarte, 2008; Naqvi et al., 2010).

Coastal hypoxia can be intermittent due to the dynamic nature of estuarine and coastal environments, where winds, tides, river discharge and circulation patterns strongly affect the ventilation of oxygen-deficient waters (Wang and Justić, 2009; Lu et al., 2018; Zhang et al., 2019). Constraints on oxygen supply can be easily eroded by changes in physical forcings, leading to the temporal alleviation of hypoxia (Laurent and Fennel, 2019). Despite the wide application of oxygen budget analysis and modelling to diagnose the dominant processes driving the formation and maintenance of hypoxia (Yu et al., 2015; Li et al., 2016; Lu et al., 2018), the evolution of intermittent hypoxia, such as the destruction and reinstatement of hypoxia from disturbance by tropical cyclones, 
remains to be better characterized (Testa et al., 2017). Specifically, the identification of key processes and timescale constraints for these hypoxia destruction and recovery processes is of critical importance in order to predict site-specific hypoxia and its cascading effects and to forecast the long-term impact of hypoxia under a changing climate with higherintensity extreme events (Knutson et al., 2010; Mendelsohn et al., 2012).

Large riverine nutrient loadings and the resulting eutrophication have recently tipped the lower Pearl River estuary (PRE) and adjacent shelf areas into seasonally hypoxic systems (Yin et al., 2004; Rabouille et al., 2008; Su et al., 2017; Qian et al., 2018; Cui et al., 2019; Zhao et al., 2020). Modelling results have shown that summer hypoxia off the PRE is largely intermittent owing to high-frequency variations in wind forcing and tidal fluctuations (Wang et al., 2017b; Huang et al., 2019). Hypoxia is often interrupted by the passage of typhoons but redevelops quickly with a tendency towards rapid oxygen declines (Su et al., 2017; Huang et al., 2019). The prevailing southwest monsoon usually favours the expansion of a quasi-steady-state freshwater bulge outside the entrance of the PRE (Gan et al., 2009b; Lu et al., 2018) that promotes water column stability. However, it remains unclear how the interaction between wind stress, tidal forcing and freshwater buoyancy affects the bottom oxygen conditions when the winds shift in the downwellingfavourable easterly or southeasterly direction, especially in the wake of tropical cyclones.

It is known that aerobic respiration of organic matter is largely responsible for the oxygen depletion here (Su et al., 2017; Qian et al., 2018). Common methods to quantify oxygen sinks under hypoxic conditions include the analysis of oxygen budgets based on the mass balance of oxygen and estimates of community/bacterial respiration or nitrification rates using field incubations (Zhang and $\mathrm{Li}, 2010$; $\mathrm{Li}$ et al., 2015; Su et al., 2017; Cui et al., 2019). However, the budget analysis of oxygen typically assumes a steady-state system (Zhang and Li, 2010; Cui et al., 2019) given that the change of oxygen over time is often much smaller than the oxygen depletion and advection or diffusion fluxes (Cui et al., 2019). The respiration or nitrification rates estimated from (enriched) incubation experiments also merely indicate the oxygen consumption rate (OCR) under a specific lowoxygen condition at the time of sampling (He et al., 2014; Su et al., 2017). The actual magnitude of in situ OCR during the hypoxia formation has rarely been reported at large scales. The role of lateral advection (and/or upwelling) also remains to be better quantified (Zhang and Li, 2010; Lu et al., 2018; Qian et al., 2018; Cui et al., 2019).

We investigated the destruction and reinstatement of summer hypoxia off the PRE to examine the effects of freshwater inputs and winds on water column stability and the maintenance, destruction and formation of hypoxia. With the aid of a three-endmember mixing model, we partitioned physicaland biochemical-induced oxygen sinks and calculated the
OCR and timescale for hypoxia regeneration after its destruction by a typhoon. The impacts of tropical cyclones on the evolution of seasonal hypoxia in river-dominated ocean margins are further discussed.

\section{Materials and methods}

\subsection{Study area and cruise background}

The shelf of the northern South China Sea (NSCS) receives an average annual freshwater discharge of $\sim 10000 \mathrm{~m}^{3} \mathrm{~s}^{-1}$ originating from the Pearl River, the 17th largest river in the world (Cai et al., 2004; Dai et al., 2014). Nearly four-fifths of freshwater discharge occurs during the wet season, typically from April to September (Dai et al., 2014). The riverine freshwater extends offshore to form a widespread plume over the shelf in summer (Gan et al., 2009b; Cao et al., 2011; Chen et al., 2017a) via eight outlets through three sub-estuaries (i.e. Lingdingyang, Modaomen and Huangmaohai; Fig. 1b). On the inner shelf, coastal upwelling interacts with the buoyant plume, which is propelled by the prevailing southwest monsoon and intensified along the eastward widened shelf (Gan et al., 2009a; Chen et al., 2017b). Climatologically, about seven tropical cyclones per year impacted the NSCS from 1949-2019, half of which featured maximum wind speeds greater than $32.7 \mathrm{~m} \mathrm{~s}^{-1}$.

Field observations and sampling were conducted aboard the R/V Haike 68 off the PRE on the inner-shelf of the NSCS in the summer of 2018. The cruise was interrupted by the passage of typhoon Son-Tinh across the NSCS, $\sim 350 \mathrm{~km}$ south of the PRE (Fig. 1a). Leg 1 (8-14 July) was the cruise period before the typhoon, and leg 2 (21-25 July) and leg 3 (2629 July) were conducted after its passage (Fig. 1b). During each leg, we collected samples from west to east and along the cross-shelf transects within isobaths of $10-35 \mathrm{~m}$. Almost all stations in leg 1 (56 stations) were revisited during leg 2 (56 stations, including 4 stations differing from leg 1) and nearly half again during leg 3 (27 stations). Eight stations were additionally revisited on the way back to the port on 31 July. Time-series observations with a sampling interval of $1 \mathrm{~h}$ were conducted at station F303 for $26 \mathrm{~h}$ before leg 2, beginning at 16:00 UTC+8 on 19 July (Fig. 1b). In contrast to the typical southwesterly winds in the NSCS with average monthly wind speeds of $<6 \mathrm{~m} \mathrm{~s}^{-1}$ from June to September (Su, 2004), easterly winds prevailed during the cruise period due to the typhoon, with the wind speeds increasing up to $\sim 13 \mathrm{~m} \mathrm{~s}^{-1}$ (Fig. 1c) at Waglan Island to the east of the study area (Fig. 1b).

\subsection{Sampling and analysis}

Temperature and salinity were determined using a SBE 917 plus conductivity-temperature-depth (CTD) recorder (Sea-Bird Electronics, Inc.). Discrete samples were collected using $5 \mathrm{~L}$ free-flow water samplers mounted 

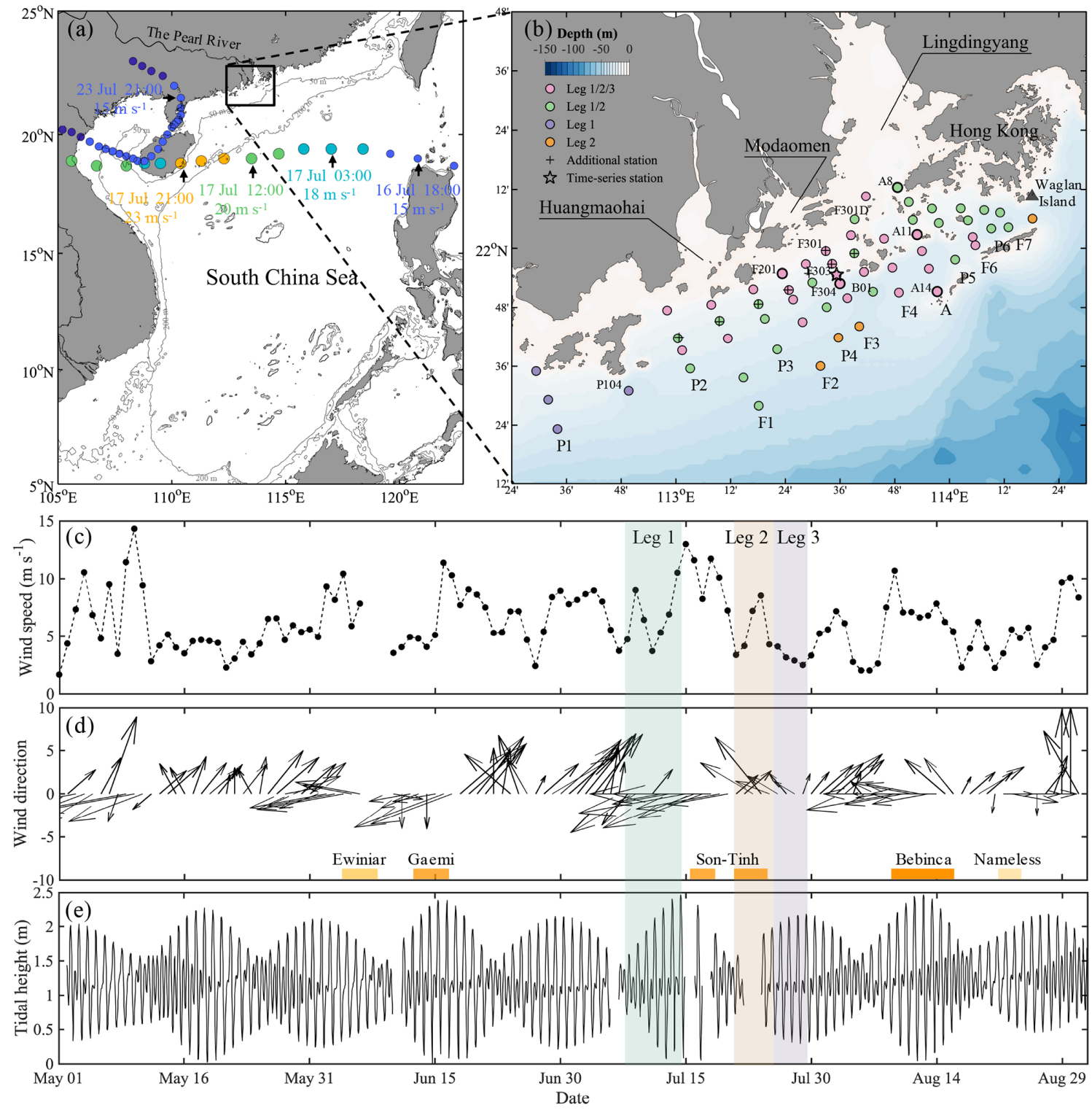

Figure 1. (a) Map of the study area on the shelf of the northern South China Sea (NSCS), showing the track of typhoon Son-Tinh (circles) across the NSCS during 16-24 July 2018. The colour of the circles represents the magnitude of wind speed. Additionally, the smaller circles denote tropical depression (wind speeds $\leq 17.1 \mathrm{~m} \mathrm{~s}^{-1}$ ) and the larger circles denote tropical storm (wind speeds within 17.2-32.6 m s $\mathrm{s}^{-1}$ ). The arrows denote the locations of the typhoon as marked with time and wind speed. The grey lines are the depth contours at 50 and $200 \mathrm{~m}$. (b) Sampling stations on the NSCS shelf off the Pearl River estuary in summer 2018. The pink, green, purple and orange circles denote the stations surveyed in all three legs, only leg 1 and leg 2, only leg 1, and only leg 2, respectively. Time-series observations were conducted at station F303 as marked by the star, and vertically high-resolution samplings were conducted at stations marked with bold circles. (c) The wind speed and (d) wind direction at Waglan Island (triangle in b) from May to August 2018. Bars at the bottom of (d) mark times when tropical cyclones impacted the NSCS. (e) The tidal height at the Dawanshan gauge station near station F303 from May to August 2018 . The shaded area indicates the cruise periods for leg 1 (grey), leg 2 (pink) and leg 3 (blue).

onto a rosette sampling assembly. Dissolved oxygen (DO), dissolved inorganic carbon (DIC), total alkalinity (TA) and chlorophyll $a(\mathrm{Chl} a)$ concentrations were measured at all stations with depth profiles from $1 \mathrm{~m}$ below the surface down to $\sim 4-6 \mathrm{~m}$ above the bottom, generally at three depth layers. Additional high-resolution vertical samplings were conducted at seven to eight depth layers (Fig. 1b).

Salinity was calibrated against discrete water samples measured by a Multi 340i salinometer (WTW). The DO concentrations were measured onboard within $\sim 12 \mathrm{~h}$ using the spectrophotometric Winkler method (Labasque et 
al., 2004), with a precision better than $\pm 2 \mu \mathrm{mol} \mathrm{L}^{-1}$. DIC was measured on $\sim 0.5 \mathrm{~mL}$ acidified water samples using an infrared $\mathrm{CO}_{2}$ detector (Apollo ASC-3) with a precision of $\pm 2 \mu \mathrm{mol} \mathrm{L}^{-1}$ (Cai et al., 2004). TA was determined on $25 \mathrm{~mL}$ samples in an open-cell setting based on the Gran titration technique (see details in Cai et al., 2010) with a Kloehn digital syringe pump. The analytical precision was $\pm 2 \mu \mathrm{mol} \mathrm{L}{ }^{-1}$. Both DIC and TA concentrations were calibrated against certified reference materials provided by Andrew G. Dickson at the Scripps Institution of Oceanography, University of California, San Diego, USA. Chl $a$ concentrations were determined using a Trilogy laboratory fluorometer (Turner Designs, Inc.) after being extracted with $90 \%$ acetone for $14 \mathrm{~h}$ at $-20^{\circ} \mathrm{C}$ (Welschmeyer, 1994) and calibrated using a Sigma $\mathrm{Chl} a$ standard.

\subsection{Water column stability}

Water column stability regulates the ventilation of subsurface waters and replenishment of DO by suppressing turbulent mixing with stratification (Obenour et al., 2012; Lu et al., 2018; Cui et al., 2019), which can be indicated by the buoyancy frequency (also known as the Brunt-Väisälä frequency),

$N^{2}=-(g / \rho)(\partial \rho / \partial z)$

where $g$ is the gravitational acceleration, $\rho$ is potential density and $z$ is the height above the seabed. Generally, a positive $N^{2}$ (i.e. $N^{2}>0 \mathrm{~s}^{-2}$ ) indicates a stable regime where stratification may suppress turbulence (Tedford et al., 2009), and a larger $N^{2}$ value indicates a more stable water column. CTD temperature and salinity were used to calculate the buoyancy frequency for sampling stations, to indicate the controls of density stratification on the development of hypoxia (Sect. 4.1).

\subsection{Oxygen consumption rate}

From the perspective of Euler observations and based on mass balance, the DO changes $(\triangle D O)$ in subsurface waters over a specified time interval at a specific site can be decomposed into two components: one driven by physical mixing $\left(\Delta \mathrm{DO}^{\mathrm{mix}}\right)$ and the other induced by biochemical processes $\left(\Delta \mathrm{DO}^{\mathrm{bc}}\right)$. Here, we define the biochemical-induced DO consumption with time as the oxygen consumption rate (OCR). A higher OCR value indicates stronger oxygen consumption, and a negative value indicates oxygen production via biochemical processes (e.g. photosynthesis). For revisited stations, $\triangle \mathrm{DO}$ is the difference in $\mathrm{DO}$ values measured between the two sampling periods. The physical-mixing-induced DO variations were derived using a three-endmember mixing model, which constructed the conservative mixing scheme among different water masses: brackish plume water (PW), offshore surface water (SW) and upwelled subsurface water (SUB) (Su et al., 2017; Cui et al., 2019; Zhao et al., 2020).
The model is constrained by salinity $(S)$ and potential temperature $(\theta)$ according to the following equations:

$f_{\mathrm{PW}}+f_{\mathrm{SW}}+f_{\mathrm{SUB}}=1$,

$S_{\mathrm{PW}} \times f_{\mathrm{PW}}+S_{\mathrm{SW}} \times f_{\mathrm{SW}}+S_{\mathrm{SUB}} \times f_{\mathrm{SUB}}=S^{\text {meas }}$,

$\theta_{\mathrm{PW}} \times f_{\mathrm{PW}}+\theta_{\mathrm{SW}} \times f_{\mathrm{SW}}+\theta_{\mathrm{SUB}} \times f_{\mathrm{SUB}}=\theta^{\text {meas }}$.

where the superscript "meas" denotes measured values, and $f$ represents the fraction that each endmember contributes to the in situ samples. Assuming that DO concentrations in surface waters before sinking to the depth were equilibrated with the atmosphere and that the subsurface waters were isolated from the atmosphere due to restriction by stratification, these fractions were applied to predict conservative concentrations of $\mathrm{DO}\left(\mathrm{DO}^{\mathrm{mix}}\right)$ resulting solely from conservative mixing.

$\mathrm{DO}^{\text {mix }}=\mathrm{DO}_{\mathrm{PW}} \times f_{\mathrm{PW}}+\mathrm{DO}_{\mathrm{SW}} \times f_{\mathrm{SW}}+\mathrm{DO}_{\mathrm{SUB}} \times f_{\mathrm{SUB}}$

Similarly, $\Delta \mathrm{DO}^{\mathrm{mix}}$ is the difference in "conservative" $\mathrm{DO}$ values between visits, assuming that the bottom water masses where biochemical oxygen consumption prevailed were constrained by strong convergence and that their outflow from the sampling area is insignificant on the timescale of the water residence time (Lu et al., 2018; Li et al., 2020). As a result,

$\mathrm{OCR}=-\Delta \mathrm{DO}^{\mathrm{bc}} / \Delta t=-\left(\Delta \mathrm{DO}-\Delta \mathrm{DO}^{\mathrm{mix}}\right) / \Delta t$,

where $\Delta t$ is the duration between the two observations at times $t_{1}$ and $t_{2}\left(t_{2}>t_{1}\right)$, and $\Delta X=X^{t_{2}}-X^{t_{1}}(X=\mathrm{DO}$, $\mathrm{DO}^{\mathrm{mix}}, \mathrm{DO}^{\mathrm{bc}}$, etc.). The uncertainty in the calculation of OCR mainly derives from the estimation of conservative values predicted from the three-endmember mixing model. Sources of the composite uncertainty $(\varepsilon)$ in derivation of $\mathrm{DO}^{\mathrm{mix}}$ are associated with potential temperature $(\theta)$, salinity $(S)$ and the dissolved oxygen (DO) values of endmembers.

$\varepsilon_{\mathrm{DO}^{\text {mix }}}=\sqrt{\sum_{i}^{n}\left[\left(f_{i} \cdot \sigma_{\mathrm{DO}_{i}}\right)^{2}+\left(\mathrm{DO}_{i} \cdot \sigma_{f_{i}}\right)^{2}\right]}$,

where $\sigma_{\mathrm{DO}}$ and $\sigma_{f}$ are uncertainties in the DO concentration and the fraction of each endmember $i$ (i.e. PW, SW and SUB), respectively, and the latter of which can be calculated as

$\sigma_{f_{i}}=\sqrt{\sum_{j}^{n}\left[\left(\partial f_{i} / \partial \theta_{j} \cdot \sigma_{\theta_{j}}\right)^{2}+\left(\partial f_{i} / \partial S_{j} \cdot \sigma_{S_{j}}\right)^{2}\right]}$,

where $j$ also denotes each endmember.

\subsection{Endmember selection and validations of the three-endmember mixing model}

The potential-temperature-salinity diagram is shown in Fig. 2a. The three-endmember mixing scheme for the bottom layer has been elucidated in Zhao et al. (2020) that had a spatial coverage similar to this study. We adopted the endmember values of the offshore surface water and upwelled subsurface water from Zhao et al. (2020) given that our sampling 
was almost exclusively within the $30 \mathrm{~m}$ isobaths (Fig. 1b), and these values were consistent with those found in previous studies (Cao et al., 2011; Guo and Wong, 2015; Su et al., 2017). The brackish plume water was assumed to partly subduct to the bottom layer under downwelling-favourable wind conditions (Huang et al., 2019; Li et al., 2021). The endmember values of the brackish plume water were thus determined from the surface water samples near the mouth of the PRE with a salinity of $\sim 16.9$, mainly consisting of a mixture of riverine freshwater and offshore surface water. The DIC endmember of brackish plume water here was consistent with the predicted value using the endmember values of riverine/plume water reported by Su et al. (2017), whereas it was higher than that calculated using the endmember values of riverine freshwater from Zhao et al. (2020) since the riverine DIC concentrations might be diluted by abnormally high river discharge in 2017 (Guo et al., 2008). For simplification, DO concentrations in offshore surface water were assumed to be saturated, in equilibrium with the atmosphere, while the upwelled subsurface water was assumed to be oxygen deficient by $\sim 16 \%$ relative to the saturation level. The DO endmember value of brackish plume water was also assumed to be equilibrated with the atmosphere, which should be in order, because the biological productivity was largely limited by high turbidity in shallow estuarine waters. A summary of the endmember values is listed in Table 1. In estimating the OCR, we excluded the above-pycnocline samples collected at depths $<10 \mathrm{~m}$ affected by the upper plume waters that are subject to strong air-sea exchanges and/or photosynthetic production of oxygen.

The predicted quasi-conservative $\mathrm{TA}\left(\mathrm{TA}^{\mathrm{pre}}=\mathrm{TA} \mathrm{PW} \times\right.$ $f_{\mathrm{RW}}+\mathrm{TA}_{\mathrm{SW}} \times f_{\mathrm{SW}}+\mathrm{TA}_{\mathrm{SUB}} \times f_{\mathrm{SUB}}$; same for DIC $\left.{ }^{\text {pre }}\right)$ is mostly consistent with our measured values (Fig. 2b), with a subtle difference of $8 \pm 8 \mu \mathrm{mol} \mathrm{kg}{ }^{-1}$ likely associated with measurement errors, computational errors in the mixing scheme and/or biological processes. The slope of $\triangle \mathrm{DIC}\left(\triangle \mathrm{DIC}^{m-p}=\mathrm{DIC}^{\text {meas }}-\mathrm{DIC}^{\text {pre }}\right)$ vs. $\Delta \mathrm{DO}^{m-p}\left(\Delta \mathrm{DO}^{m-p}=\mathrm{DO}^{\text {meas }}-\mathrm{DO}^{\text {mix }}\right)$ in bottom waters was $-0.93 \pm 0.07$ (Fig. 2c), similar to that reported by Zhao et al. (2020).

\section{Evolution of intermittent hypoxia off the PRE}

\subsection{Extensive hypoxia before the typhoon}

The water columns showed a prominent two-layer structure on the inner NSCS shelf off the PRE (Figs. 3 and 4). In the surface layer, the freshwater plume mainly attached to the coast when veering to the west as constrained by estuarine topography, the Coriolis force (Wong et al., 2003) and easterly winds during leg 1 (Fig. 1d), despite a freshwater bulge that remained near the mouth of the Lingdingyang sub-estuary due to persistent southwesterly winds before the cruise (Fig. 1d) and the weak shelf current there (Gan et al., 2009b; Lu et al., 2018). A strong bloom occurred in the surface plume waters near the Huangmaohai sub-estuary, characterized by high Chl $a$ concentrations of $>20 \mu \mathrm{g} \mathrm{L}-1$ and oversaturated DO of $>300 \mu \mathrm{mol} \mathrm{kg}^{-1}$ (equivalent to a DO saturation level $>150 \%$ ) (Fig. $3 \mathrm{~g}, \mathrm{j}$ ). The freshwater bulge also featured a relatively weak bloom, with $\mathrm{Chl} a$ concentrations of $\sim 10 \mu \mathrm{g} \mathrm{L}^{-1}$ and DO of $\sim 250 \mu \mathrm{mol} \mathrm{kg}^{-1}$ (equivalent to a DO saturation level of $\sim 125 \%$ ). Similar blooms were previously observed to be associated with high nutrient concentrations, a sufficiently long water residence time and an abundance of photosynthetically active radiation $(\mathrm{Lu}$ and Gan, 2015). The surface water temperature was mostly $>29^{\circ} \mathrm{C}$. Exceptions occurred to the southwest of Hong Kong (Fig. 3a) where the air temperature was $2-3^{\circ} \mathrm{C}$ lower at the time of sampling (Fig. S1 in the Supplement).

At the bottom layer, low-temperature $\left(<26^{\circ} \mathrm{C}\right)$, highsalinity ( $>33$ ) deep shelf waters intruded upslope to the 10 $20 \mathrm{~m}$ isobaths beneath the surface plume (Fig. 4a, d). An extensive hypoxic zone ( $\mathrm{DO}<63 \mu \mathrm{mol} \mathrm{kg}{ }^{-1}$ ) developed beneath the freshwater bulge and extended westwards along the $20-30 \mathrm{~m}$ isobaths to the region off the Modaomen subestuary (Fig. 4g). To the east, a relatively weak hypoxic centre occurred adjoining the Hong Kong waters. Additionally, a smaller-scale hypoxic zone appeared beneath the surface bloom near the Huangmaohai sub-estuary, a region where hypoxia was also reported but not fully covered by survey measurements (Su et al., 2017; Cui et al., 2019). The general spatial pattern of hypoxic centres was similar to that found in summers of 2014 and 2017 (Su et al., 2017; Zhao et al., 2020) yet with a slight offshore shift. The minimum oxygen level was $3.5 \mu \mathrm{mol} \mathrm{kg}{ }^{-1}\left(\sim 0.1 \mathrm{mg} \mathrm{L}^{-1}\right)$ in bottom waters at station F303, which was lower than the previously reported minimum $\left(\sim 7 \mu \mathrm{mol} \mathrm{kg}^{-1}\right.$ at station F304; $\mathrm{Su}$ et al., 2017). Within the surveyed region where DO concentrations were interpolated into $0.5^{\prime} \times 0.5^{\prime}$ grids using the Kriging interpolation method, the total area of the hypoxic zone reached $\sim 660 \mathrm{~km}^{2}$, and the oxygen-deficit zone (DO $<94 \mu \mathrm{mol} \mathrm{kg}-1$ ) occupied $\sim 1470 \mathrm{~km}^{2}$, which was larger than those in summer $2014\left(>280 \mathrm{~km}^{2}\right.$ for the hypoxic zone and $>800 \mathrm{~km}^{2}$ for the oxygen-deficit zone) when we surveyed in a smaller area (Su et al., 2017). Cui et al. (2019) reported that spring-neap tidal oscillations lead to variations in the DO concentration outside of the Lingdingyang sub-estuary with a maximum neighbouring oxygen range of $\sim 15 \mu \mathrm{mol} \mathrm{kg}{ }^{-1}$. As our observations were conducted during the transition from the neap tide to the spring tide (Fig. 1e), the total areas of the hypoxic zone and the oxygen-deficit zone would be at most $\sim 990$ and $\sim 1930 \mathrm{~km}^{2}$, respectively, which are $34 \%-50 \%$ larger than our observed areas.

\subsection{Destruction of hypoxia by the typhoon}

The spatial patterns of temperature, salinity, DO and Chl $a$ concentrations all changed drastically from disturbance by intensified easterly winds during the typhoon period. Strong 

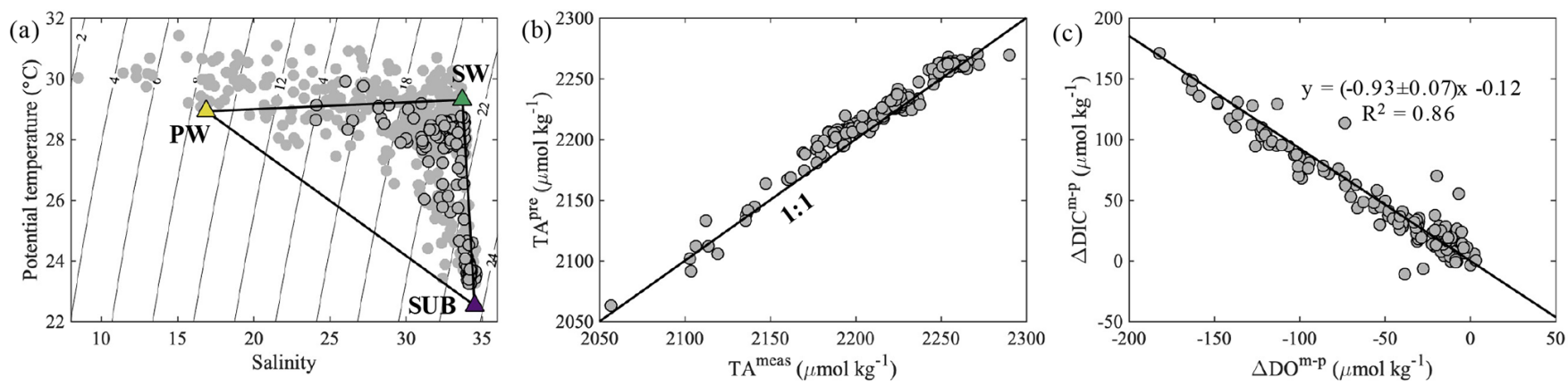

Figure 2. (a) Potential temperature $\left({ }^{\circ} \mathrm{C}\right)$ vs. salinity, (b) predicted $\mathrm{TA}\left(\mathrm{TA}^{\text {pre }}, \mu \mathrm{mol} \mathrm{kg}{ }^{-1}\right)$ vs. measured $\mathrm{TA}^{(\mathrm{TA}}{ }^{\mathrm{meas}}, \mu \mathrm{mol} \mathrm{kg}{ }^{-1}$ ) and (c) $\Delta \mathrm{DIC}^{m-p}\left(\mu \mathrm{mol} \mathrm{kg} \mathrm{kg}^{-1}\right)$ vs. $\Delta \mathrm{DO}^{m-p}\left(\mu \mathrm{mol} \mathrm{kg}{ }^{-1}\right)$ on the NSCS shelf off the PRE. The black-edged circles represent bottom water samples with depths $>10 \mathrm{~m}$. The yellow, green and purple triangles in (a) represent the endmember values of brackish plume water (PW), offshore surface water (SW) and upwelled subsurface water (SUB), respectively. The black line in (c) denotes the slope of $\Delta \mathrm{DIC}-p$ plotted against $\Delta \mathrm{DO}^{m-p}$ derived from the Model II regression.

Table 1. Summary of the endmember values adopted in the three-endmember mixing model.

\begin{tabular}{lrrrr}
\hline Water mass & $\theta\left({ }^{\circ} \mathrm{C}\right)$ & Salinity & DIC $\left(\mu \mathrm{mol} \mathrm{kg}{ }^{-1}\right)$ & DO $\left(\mu \mathrm{mol} \mathrm{kg}{ }^{-1}\right)$ \\
\hline Brackish plume water $^{\mathrm{a}}$ & $28.9 \pm 0.4^{\mathrm{b}}$ & 16.9 & $1776 \pm 29^{\mathrm{b}}$ & $217.3 \pm 1.4^{\mathrm{c}}$ \\
Offshore surface water $^{\mathrm{c}}$ & $29.3 \pm 0.1$ & $33.7 \pm 0.1$ & $1922 \pm 5$ & $194.4 \pm 0.3^{\mathrm{c}}$ \\
Upwelled subsurface water $^{\mathrm{a}}$ & $22.5 \pm 0.1$ & $34.5 \pm 0.0$ & $2022 \pm 3$ & $180.9 \pm 0.4^{\mathrm{c}}$ \\
\hline
\end{tabular}

${ }^{\mathrm{a}}$ Adopted from Zhao et al. (2020). ${ }^{\mathrm{b}}$ Uncertainties were derived from multiple samples collected at the entrance of the PRE.

${ }^{\mathrm{c}}$ Uncertainties were calculated by propagating errors associated with the estimation of oxygen solubility using Benson and Krause (1984).

winds drove the warm, low-salinity and oxygen-saturated surface waters to mix downward, increasing temperature and DO concentrations and decreasing salinity in bottom waters (Fig. 4). Time-series observations at station F303 before leg 2 showed a vertically well-mixed water column in the first half, as reflected by homogeneous distributions of intermediate temperature $\left(\sim 28^{\circ} \mathrm{C}\right)$, salinity $(\sim 32)$ and DO levels $\left(\sim 180 \mu \mathrm{mol} \mathrm{kg}^{-1}\right)$ (Fig. 5a-c). The less well-mixed water column in the second half of the time-series observations likely resulted from the weakened winds, showing an upward intrusion of bottom waters which were slightly warmer than surface waters which lost heat to the low-temperature atmosphere (Fig. S1). With subdued winds that shifted to southwesterly in the following $2 \mathrm{~d}$ (Fig. 1c, d), the offshore spreading of the river plume suppressed the upward intrusion of slightly warm bottom waters and facilitated the restoration of a two-layer water column, as observed in the second half of the time-series observations (Fig. 5) and during leg 2 (Figs. 3 and 4). Large phytoplankton blooms were identified in the surface plume, widely spreading from the mouth of the Lingdingyang sub-estuary to near the Huangmaohai subestuary (Fig. 3k), potentially fuelled by nutrients mixed upward from the depth in addition to riverine inputs (Wang et al., 2017b; Qiu et al., 2019). The maximum Chl $a$ concentration was $>40 \mu \mathrm{g} \mathrm{L}^{-1}$ off the Modaomen sub-estuary, accompanied by an extraordinarily high DO concentration of $>350 \mu \mathrm{mol} \mathrm{kg}^{-1}$ (Fig. 3h, k). The surface water temperature was $\sim 29.0 \pm 0.5^{\circ} \mathrm{C}$, which was higher than that in bottom waters by $0.8^{\circ} \mathrm{C}$ during leg 2 (Figs. $3 \mathrm{~b}$ and $4 \mathrm{~b}$ ).

In bottom waters, hypoxia had been completely destroyed due to strong reaeration in the wake of the typhoon travelling across the NSCS, replaced by a homogenous spatial distribution of relatively high DO concentrations $\left(\sim 171 \pm 16 \mu \mathrm{mol} \mathrm{kg}^{-1}\right)$ during leg 2 (Fig. 4h). The cross-shore gradients in temperature and salinity were also largely relaxed, with isotropically elevated temperatures up to $\sim 28^{\circ} \mathrm{C}$ and decreased salinity (Fig. $4 \mathrm{~b}$, e). The mid-depth distributions of temperature, salinity and DO concentrations showed similar patterns as at the bottom layer (Fig. S2). Although the water column remained relatively well-mixed in the subsurface layer, freshwater buoyancy and weakened winds facilitated the revitalization of density stratification and subsequent oxygen decline below the pycnocline. Indeed, the bottom water DO concentration at station F303 decreased by $\sim 18 \mu \mathrm{mol} \mathrm{kg}{ }^{-1}$ compared to that in the timeseries observations and was lower than that at adjacent stations by $\sim 9-22 \mu \mathrm{mol} \mathrm{kg}^{-1}$ when revisited during leg 2 on 22 July (Fig. S3).

\subsection{Reinstatement of hypoxia after the typhoon}

With the dying out of the typhoon after its landfall to the west of the study area on 23 July (Fig. 1a), the wind speed decreased to $<5 \mathrm{~m} \mathrm{~s}^{-1}$ on 25 July, while the wind direction 

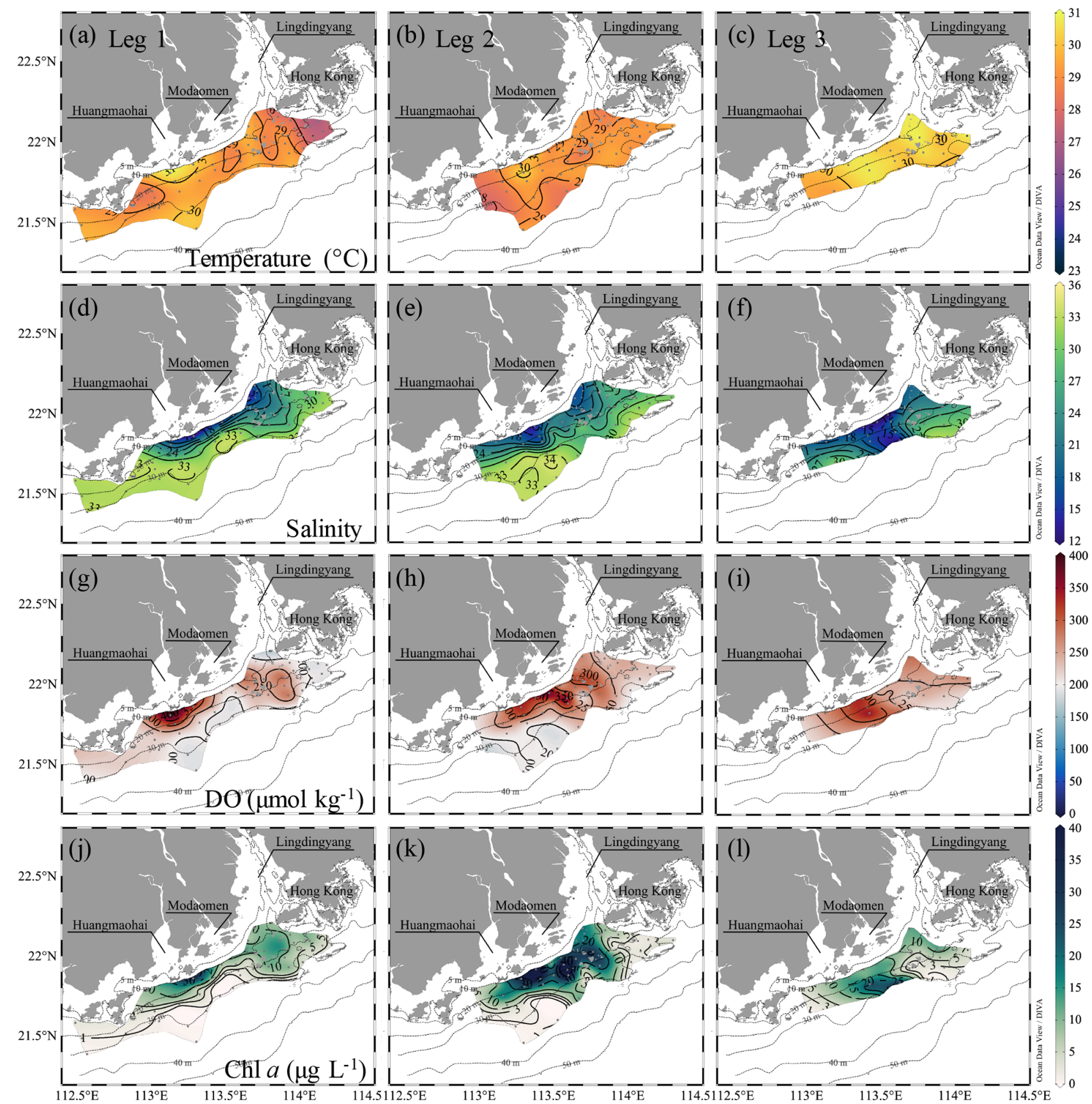

Figure 3. Distributions of temperature $\left({ }^{\circ} \mathrm{C}\right)$, salinity, DO $\left(\mu \mathrm{mol} \mathrm{kg}{ }^{-1}\right)$ and $\mathrm{Chl} a$ concentrations $\left(\mu \mathrm{L} \mathrm{L}^{-1}\right)$ at the surface water layer off the PRE during pre-typhoon leg 1 and during post-typhoon legs 2 and 3. The white and magenta contours in (g) and (w) show the hypoxic $\left(\mathrm{DO}<63 \mu \mathrm{mol} \mathrm{kg}^{-1}\right.$ ) and oxygen-deficit $\left(\mathrm{DO}<94 \mu \mathrm{mol} \mathrm{kg}^{-1}\right.$ ) zones, respectively. Figures were produced using Ocean Data View v. 5.3 .0 (http://odv.awi.de, last access: 8 June 2020, Schlitzer, 2018).

remained from the southeast before it shifted to southwesterly on 29 July (Fig. 1c, d). The DO concentrations in bottom waters were noticeably lower $\left(139-164 \mu \mathrm{mol} \mathrm{kg}^{-1}\right.$ shallower than $20 \mathrm{~m}$ isobaths), starting around July 23 in the second half of leg 2 (Figs. 1b and 4h). During leg 3 from 2629 July, hypoxia was present again in bottom waters, due to favourable conditions for its formation (Figs. 3 and 4). The surface layer was warmed up to over $30^{\circ} \mathrm{C}$ (Fig. 3c), increasing vertical thermal gradients relative to leg 2 (Figs. 3 and 4) and strengthening the stratification (Allahdadi and Li, 2017). The freshwater bulge of lower salinity $(<15)$ advected offshore around the Modaomen sub-estuary, with the offshore migration of the bloom (Fig. 4f, 1) likely driven by the interaction between the seaward buoyant current and northeast- 

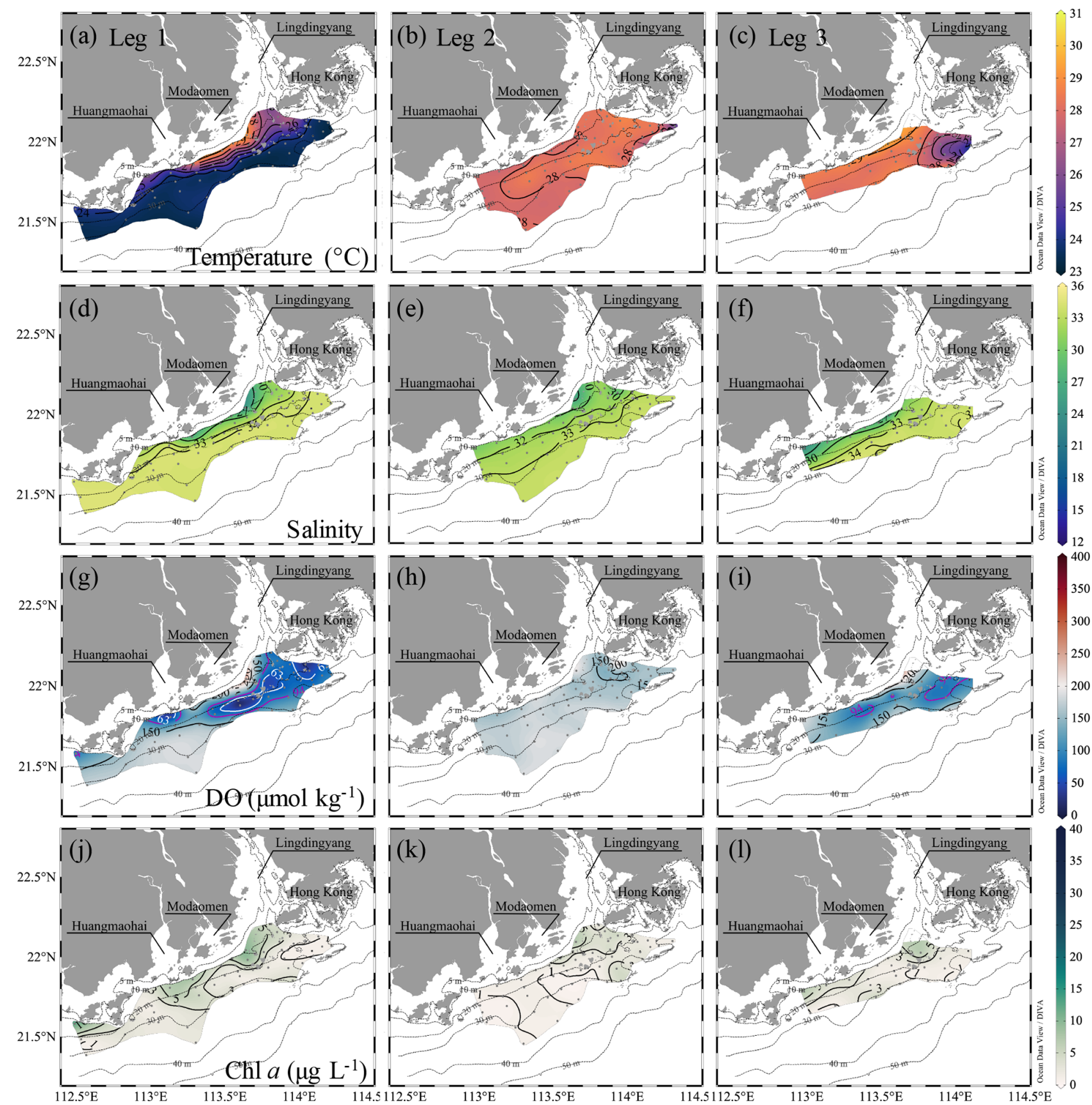

Figure 4. Distributions of temperature $\left({ }^{\circ} \mathrm{C}\right)$, salinity, DO $\left(\mu \mathrm{mol} \mathrm{kg}{ }^{-1}\right)$ and $\mathrm{Chl} a$ concentrations $\left(\mu \mathrm{L} \mathrm{L}^{-1}\right)$ at the bottom water layer off the PRE during pre-typhoon leg 1 and during post-typhoon legs 2 and 3. The white and magenta contours in (g) and (w) show the hypoxic $\left(\mathrm{DO}<63 \mu \mathrm{mol} \mathrm{kg}^{-1}\right)$ and oxygen-deficit $\left(\mathrm{DO}<94 \mu \mathrm{mol} \mathrm{kg}^{-1}\right)$ zones, respectively.

ward shelf current (Pan et al., 2014; Li et al., 2020). The Chl $a$ concentrations near the entrances of the three subestuaries remained relatively high $\left(>10 \mu \mathrm{g} \mathrm{L}^{-1}\right)$, and the DO concentrations remained at high levels of $>250 \mu \mathrm{mol} \mathrm{kg}{ }^{-1}$, which were $\sim 20 \%$ over the saturation levels (Fig. 3i, 1).

Similar to leg 1 and leg 2, the surface waters penetrated into the subsurface layer along the coast (Fig. 4f), likely forced by the downwelling-favourable winds (Fig. 1d)
(Huang et al., 2019; Li et al., 2021), augmenting temperature and DO concentrations but bringing down salinity, particularly in the mid-depth layer from $3-5 \mathrm{~m}$ at stations nearest the shore to $\sim 15 \mathrm{~m}$ at stations furthest from the shore (Fig. S2). The downward penetration of surface waters, nonetheless, seemed to be restricted to the $\sim 10 \mathrm{~m}$ isobath and thus offset only a limited amount of the oxygen reduction caused by biochemical consumption (Koweek et 


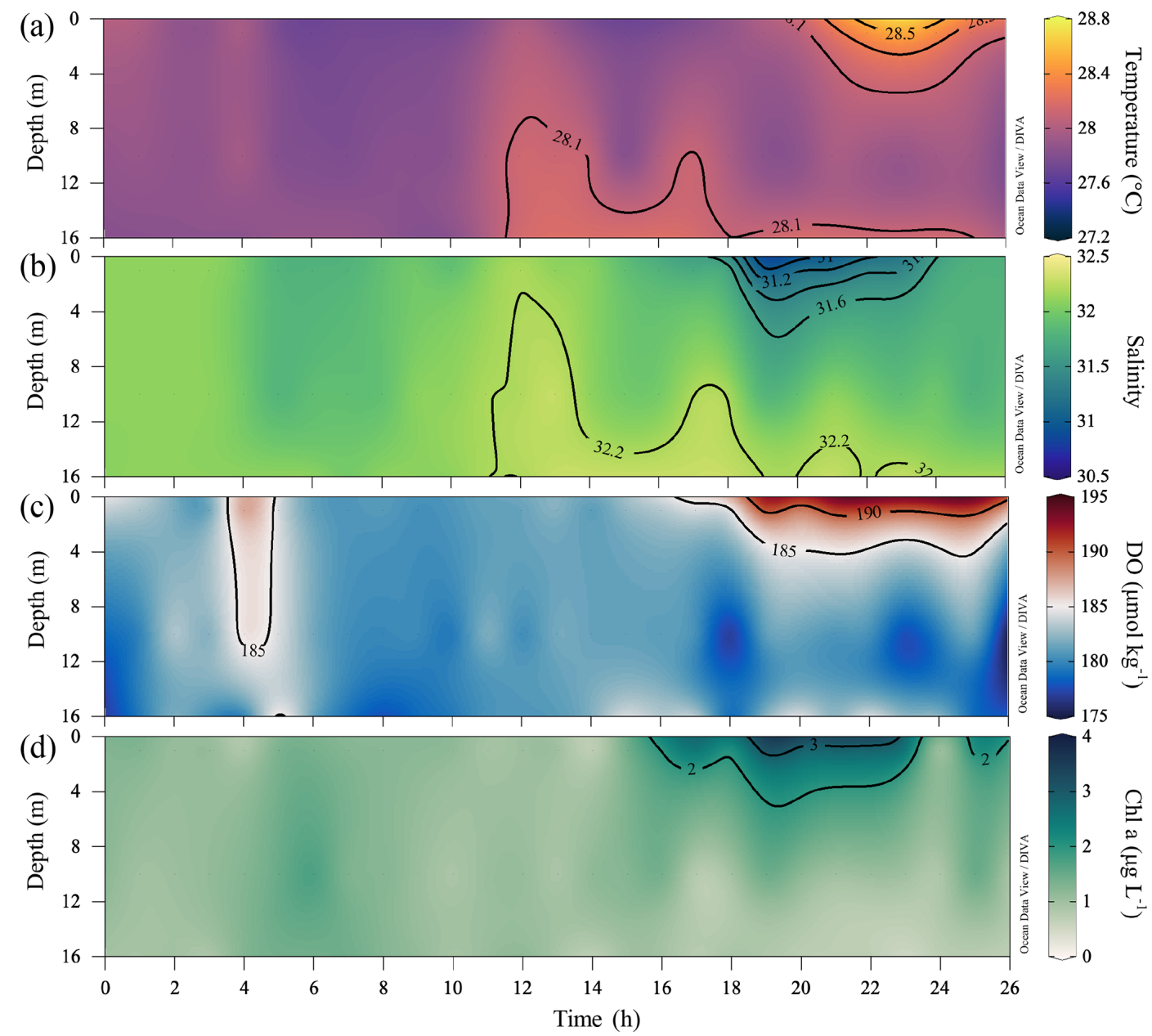

Figure 5. Time-series observations of (a) temperature $\left({ }^{\circ} \mathrm{C}\right)$, (b) salinity, (c) DO ( $\mu \mathrm{mol} \mathrm{kg}^{-1}$ ) and (d) Chl $a$ concentrations ( $\left.\mu \mathrm{g} \mathrm{L}{ }^{-1}\right)$ at station F303 (see Fig. 1b) from 19-20 July 2018 after the typhoon passage, showing the complete destruction and the subsequent rapid development of stratification.

al., 2020). DO concentrations in bottom waters were reduced to $\sim 46 \mu \mathrm{mol} \mathrm{kg}{ }^{-1}$ off the Modaomen sub-estuary along the $20 \mathrm{~m}$ isobaths and to $<94 \mu \mathrm{mol} \mathrm{kg}{ }^{-1}$ to the southwest of Hong Kong (Fig. 4i), indicating the reinstatement of hypoxia. When sites were revisited on 31 July, the re-emerging hypoxia was found to have been strengthened, with oxygen levels down to $\sim 37 \mu \mathrm{mol} \mathrm{kg}^{-1}$. We found that hypoxia formed in bottom waters with a temperature of $\sim 28^{\circ} \mathrm{C}$ off the Modaomen sub-estuary during leg 3 , while the oxygendeficit zone to the southwest of Hong Kong showed a relatively low temperature of $<27^{\circ} \mathrm{C}$ (Fig. 4c), likely due to the cross-isobath transport of deep shelf waters, arising from local topographic effects (Dai et al., 2014; Wang et al., 2014) as during leg 1 . In this sense, the shoreward intrusion of deep shelf waters is not a prerequisite for the initiation of hypoxia formation off the PRE, but it contributes to the reinstatement of hypoxia southwest off Hong Kong.

\section{Physical and biogeochemical controls on the evolution of intermittent hypoxia}

\subsection{Water column stability}

A stable water column is a key prerequisite for the formation and maintenance of hypoxia in coastal oceans (Wang and Justić, 2009; Obenour et al., 2012; Testa and Kemp, 2014; Lu et al., 2018; Zhang et al., 2019), which restricts the oxygen supply by suppressing advective and diffusive mixing with oxygen-rich waters (Murphy et al., 2011; Cui et al., 2019). Many studies have demonstrated that density stratification becomes enhanced and stabilizes subsurface waters when freshwater flows over seawater (Gan et al., 2009b; MacCready et al., 2009; Bianchi et al., 2010), allowing oxygen depletion over a longer timescale (Fennel and Testa, 2019). In the second half of the time-series observations, the twolayer structure re-emerged with the spreading of the river plume, which suppressed the vertical mixing in the subsur- 
face layer, as reflected by the receded upward intrusion of slightly warm, saline bottom waters (Fig. 5a, b). The Chl $a$ concentrations in the surface layer increased, followed by an elevated DO level in surface waters and a lowered DO level in subsurface waters (Fig. 5c, d). The surface-to-bottom salinity difference showed large values within the surface plume area, which almost covered the bottom hypoxic zones (Fig. 4g, i). Exceptions only occurred to the hypoxic zone off the Modaomen sub-estuary, where the surface-to-bottom salinity differences were relatively small but the temperature differences were large (i.e. $\Delta T_{\mathrm{b}-\mathrm{s}}<-4{ }^{\circ} \mathrm{C}$ in Fig. $6 \mathrm{a}-$ c) due to the shoreward intrusion of cold deep shelf waters (Fig. $4 \mathrm{a}-\mathrm{c}$ ). The regions occupied by the surface plume and the shoreward-intruded deep shelf waters therefore overlapped, resulting in a more stable water column where a patchy hypoxic zone could persist for more than $5 \mathrm{~d}$ (Cui et al., 2019).

Off the PRE, when not influenced by freshwater inputs, the surface layer showed a relatively small $N^{2}$ close to $0 \mathrm{~s}^{-2}$ and vertically well-mixed temperature, salinity and DO concentrations (e.g. in the top $\sim 10 \mathrm{~m}$ at station A14, Fig. 7c). However, in the presence of the freshwater plume, the surface layer became more stable, with a larger $N^{2}$ of $>1 \times 10^{-3} \mathrm{~s}^{-2}$, or even $>5 \times 10^{-3} \mathrm{~s}^{-2}$ (e.g. stations A8 and A11, Fig. 7a, b). The DO concentrations decreased sharply at the base of the surface plume (salinity $\sim 30)$. Using the eddy diffusivity for density $\left(K_{z}\right)$ of $<5 \times 10^{-6} \mathrm{~m}^{2} \mathrm{~s}^{-1}$ for $N^{2}$ larger than $1 \times 10^{-3} \mathrm{~s}^{-2}$ (Cui et al., 2019), we estimated the vertical diffusion for DO concentrations $\left(\mathrm{VDIF}=K_{z} \times(\partial \mathrm{DO} / \partial z)\right)$ of $\sim 0.25 \mathrm{~g} \mathrm{~m}^{-2} \mathrm{~d}^{-1}$ with a maximum of $0.54 \mathrm{~g} \mathrm{~m}^{-2} \mathrm{~d}^{-1}$ in the top $10 \mathrm{~m}$ at stations A8 and A11, which was comparable to the results from Cui et al. (2019). It therefore acted as a barrier layer, with weak dissipation of oxygen into the subsurface waters. The inherent pycnocline between the offshore surface water and deep shelf waters mainly driven by steep temperature gradients (Qu et al., 2007), such as at station A14, acted as a second pycnocline in the plume region (e.g. stations A8 and A11, Fig. 7a) yet with weaker stratification likely from increased shear stresses in shallower waters (Pan and Gu, 2016; Li et al., 2020). At the edge of the freshwater plume (Figs. 1b and 3a), such as station F304, the second pycnocline was more stable than that induced by freshwater inputs (Fig. 7d). This three-layer structure, separated by two pycnoclines, therefore effectively decreased oxygen influx from the surface and facilitated oxygen depletion in bottom waters.

Water column stability also largely depends on wind stress and/or direction in coastal waters (Wilson et al., 2008; Wang and Justić, 2009). Higher wind stress usually de-stratifies the water column, leading to stronger turbulent mixing, air-sea gas exchange and reaeration (Chen et al., 2015; Lu et al., 2018; Huang et al., 2019), relieving hypoxic conditions (Ni et al., 2016; Wei et al., 2016). During the typhoon period, the wind speed rose to as high as $13 \mathrm{~m} \mathrm{~s}^{-1}$ (Fig. 1c), which was large enough to break the stratification (Geng et al., 2019) driven by freshwater inputs and the inherent thermocline and resulted in a vertically well-mixed water column (Fig. 5). The surface waters became undersaturated $(\sim 90 \%$ of the oxygen saturation level) due to the upward mixing of lowoxygen waters, which in turn favoured the ventilation of bottom waters and the breakdown of hypoxic conditions ( $\mathrm{Hu}$ et al., 2017). Despite wind speeds still as high as $10 \mathrm{~m} \mathrm{~s}^{-1}$ during leg 2 (Fig. 1c), stratification was regenerated in the top $\sim 10 \mathrm{~m}$ of the plume region, which had relatively large surface-to-bottom salinity differences (Fig. 6e) and high $N^{2}$ (Fig. 7e-h) under easterly winds (Fig. 1d). This suggests that freshwater input-induced stratification suppressed turbulent mixing driven by wind stress, favouring the initiation of hypoxia development even under downwelling-favourable conditions. Most modelling work simulated the formation of hypoxia off the PRE under the typical summer southwest monsoon (Wei et al., 2016; Lu et al., 2018; Li et al., 2020; Yu et al., 2020); when southwest winds blow in a more southward direction, a larger hypoxic zone develops (Wei et al., 2016). In contrast to southwesterly winds that facilitate the wide eastward spreading of the surface plume (Gan et al., $2009 \mathrm{~b}$ ), the downwelling-favourable easterly winds tend to constrain the surface plume to flow westward near the coast (Li et al., 2021) as shown during leg 2 and even drive the surface oxygen-saturated waters to penetrate into the deep along the coast (Figs. S2 and 4), resulting in an offshore or westward shift of the hypoxic zones that only partly overlapped with the surface plume in terms of their localities. If the easterly winds last for a longer time than the hypoxia formation timescale, stronger blooms in the surface plume (Fig. 3k) would enhance the bottom hypoxia with abundant supply of fresh, labile organic matter, but the downwellingfavourable winds would also destroy the bottom hypoxia if the wind stresses become strong enough (Li et al., 2021).

\subsection{Oxygen sinks and hypoxia formation timescale}

\subsubsection{Mixing-induced oxygen sinks}

With the restoration of density stratification from leg 2 to leg 3, DO concentrations in bottom waters were generally reduced by $>25 \mu \mathrm{mol} \mathrm{kg}{ }^{-1}$, with two hotspots showing reductions up to $75 \mu \mathrm{mol} \mathrm{kg}-1$ : one located offshore of the Lingdingyang sub-estuary, to the southwest of Hong Kong, and the other between the Modaomen and Huangmaohai sub-estuaries (Fig. 8a). The mixing-induced DO changes were positive along the coast within $10-20 \mathrm{~m}$ isobaths, as the oxygen-saturated surface waters penetrated downward to re-aerate the bottom waters driven by the downwelling-favourable easterly winds (Huang et al., 2019). The mixing-induced oxygen sinks mainly occurred in bottom waters southwest off Hong Kong, with an average of $-5.7 \pm 0.8 \mu \mathrm{mol} \mathrm{kg}-1$, which was higher than in other regions west of the PRE (e.g. beyond the $20 \mathrm{~m}$ isobath; $-1.4 \pm 0.8 \mu \mathrm{mol} \mathrm{kg}^{-1}$ ) (Fig. $8 \mathrm{~b}$ ). The mixing-induced oxy- 


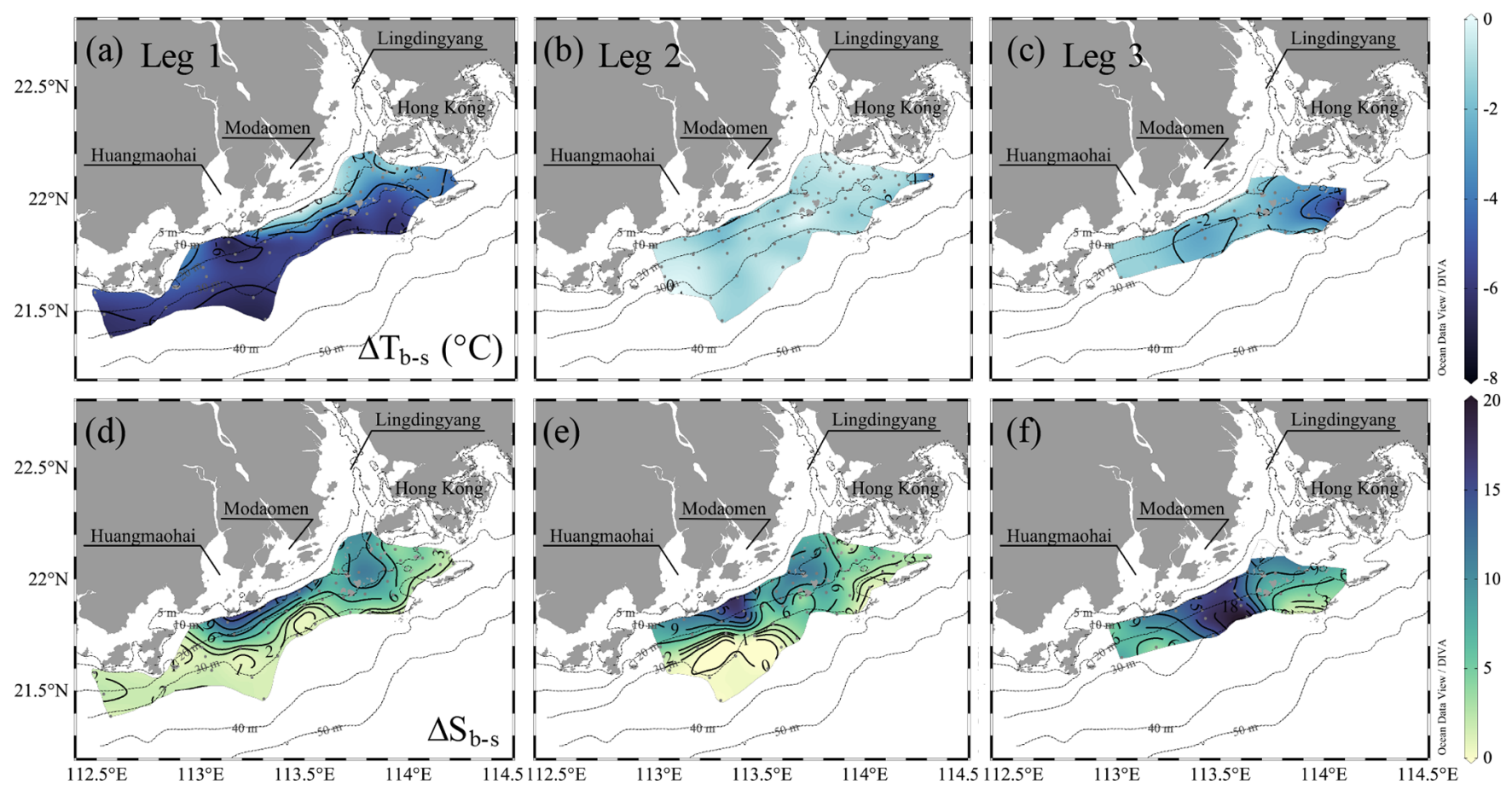

Figure 6. The surface-to-bottom temperature (a-c) and salinity (d-e) distributions off the PRE during pre-typhoon leg 1 and post-typhoon during legs 2 and 3. $\Delta T_{\mathrm{b}-\mathrm{s}}$ and $\Delta S_{\mathrm{b}-\mathrm{s}}$ represent the difference in temperature and salinity, respectively, between the bottom and surface layer.

gen sinks can be attributed to the shoreward intrusion of oceanic, cold oxygen-undersaturated subsurface waters - as reflected by lowered temperature $\left(<27^{\circ} \mathrm{C}\right.$; Fig. 4c $)$, which usually act as a non-local driver of coastal hypoxia by lowering the initial DO concentration (Wang, 2009; Qian et al., 2017). The cold, saline oceanic subsurface waters also completely occupied the bottom layer beyond the $20 \mathrm{~m}$ isobath during leg 1, where extensive hypoxia developed (Fig. 4a, g). This upwelling-induced reduction in the initial DO level amounted to $8.6 \pm 1.7 \%$ of the oxygen decline to the southwest of Hong Kong, suggesting coastal upwelling played a minor role in the hypoxia formation.

The contribution of oxygen-deficient coastal upwelling to the hypoxia formation varies in different ocean marginal systems, which is largely dependent on the source of the subsurface water masses and biogeochemical reactions along the pathway of the intrusion. Qian et al. (2017) showed the apparent oxygen utilization (AOU) values of $\sim 50 \mu \mathrm{mol} \mathrm{kg}^{-1}$ in the source waters of the nearshore Kuroshio branch at the shelf break northeast of Taiwan and an AOU increment of $\sim 40 \mu \mathrm{mol} \mathrm{kg}{ }^{-1}$ throughout its travel time of $\sim 60 \mathrm{~d}$ to the vicinity off the Changjiang river (Yang et al., 2013). In eastern boundary upwelling systems along the northeast $\mathrm{Pa}$ cific Ocean, the source waters typically have a low DO concentration of $\sim 80-160 \mu \mathrm{mol} \mathrm{kg}^{-1}$, even near or below hypoxic levels from a depth of $\sim 100-200 \mathrm{~m}$ (Grantham et al., 2004). The DO deficits were further exacerbated by respi- ration when the source waters transited shoreward over the shelf. Comparing with these systems, the source water originating from the low-latitude high-temperature oligotrophic NSCS (Wong et al., 2007) has a higher DO level (AOU $\left.\sim 35 \mu \mathrm{mol} \mathrm{kg}{ }^{-1}\right)$. As the NSCS shelf is narrower than the East China Sea shelf, the source water spends a shorter time intruding towards the coastal zone after diverting its direction from the continental slope (Gan et al., 2009a; Wang et al., 2014). These might explain the relatively low contribution of coastal upwelling to the oxygen depletion on the inner NSCS shelf off the PRE.

\subsubsection{Biochemical-induced oxygen sinks}

The biochemical-induced DO and DIC changes from leg 2 to leg 3 also showed a good relationship with a slope of $-0.92 \pm 0.17$ (Fig. 8d), consistent with the slope of biochemical-induced variations in DO against DIC concentrations throughout the sampling legs (Fig. 2c), implying that aerobic respiration of organic matter indeed dominated the oxygen consumption. The distribution of OCR estimates in bottom waters almost mirrored variations in the total DO pattern from leg 2 to leg 3 (Fig. 8a, c). This biochemically mediated OCR ranged from $0.9 \mu \mathrm{mol} \mathrm{O}_{2} \mathrm{~kg}^{-1} \mathrm{~d}^{-1}$ at offshore non-hypoxic stations to $19.5 \pm 0.4 \mu \mathrm{mol} \mathrm{O}_{2} \mathrm{~kg}^{-1} \mathrm{~d}^{-1}$ in hypoxic waters, with an average of $14.6 \pm 4.8 \mu \mathrm{mol} \mathrm{O} \mathrm{kg}^{-1} \mathrm{~d}^{-1}$ in the oxygen-deficit zone. The uncertainty introduced by the mixing scheme was 


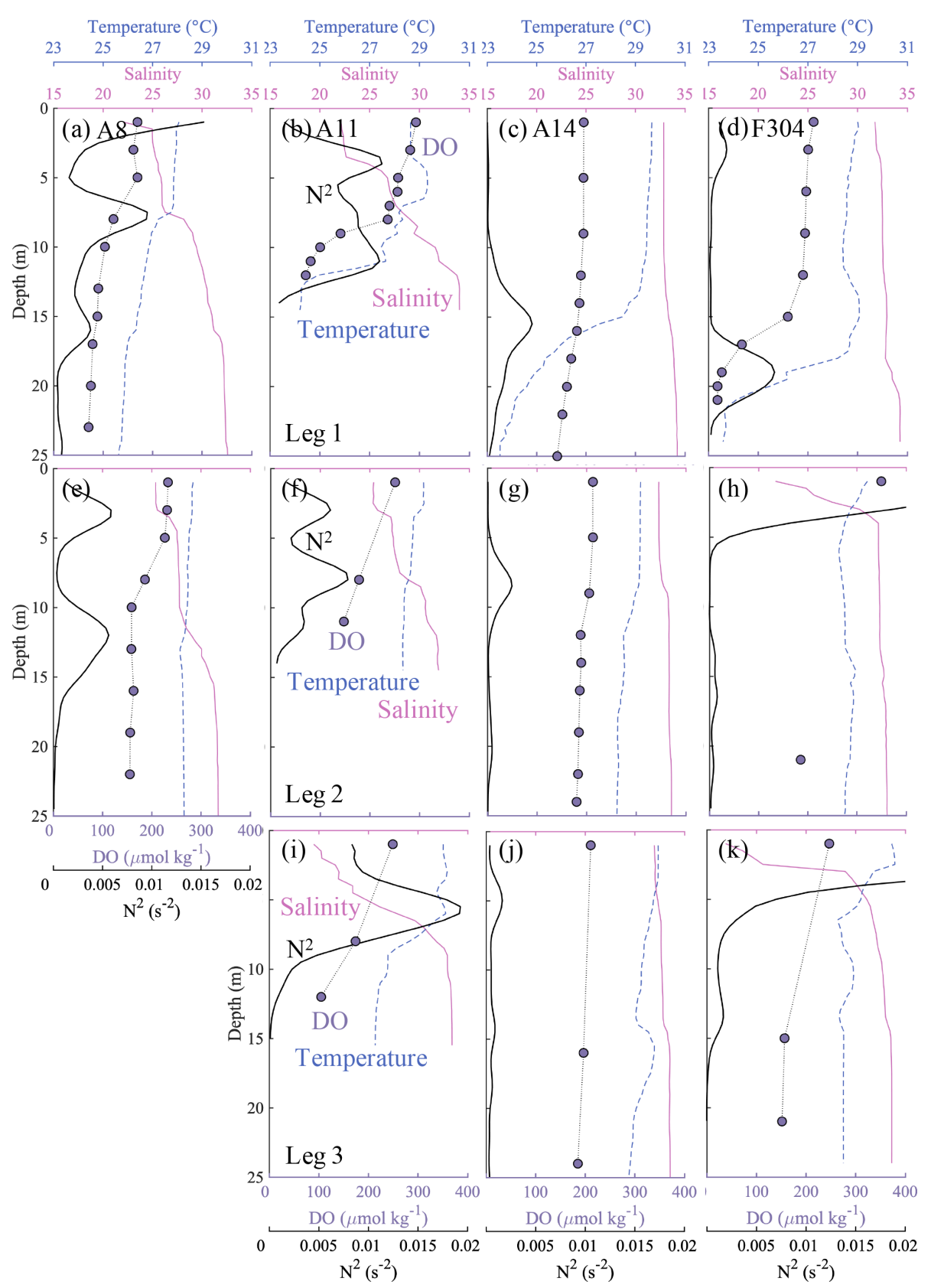

Figure 7. Profiles of temperature $\left({ }^{\circ} \mathrm{C}\right)$ (blue dashed lines), salinity (pink solid lines), dissolved oxygen $\left(\mathrm{DO}, \mu \mathrm{mol} \mathrm{kg}{ }^{-1}\right)$ (purple dots) and buoyancy frequency $N^{2}\left(\mathrm{~s}^{-2}\right)$ (bold black solid lines) at stations A8, A11, A14 and F304 (see Fig. 1b), with visits for both pre-typhoon (leg 1) and post-typhoon periods (legs 2 and 3). The vertical distributions of $N^{2}$ have been smoothed by the Gaussian method.

0.63-0.98 $\mu \mathrm{mol} \mathrm{O} \mathrm{kg}^{-1} \mathrm{~d}^{-1}$, accounting for a deviation of $4 \%-27 \%$. The geographical locations of high-OCR zones at the bottom layer (OCR $>10 \mu \mathrm{mol} \mathrm{O} \mathrm{kg}^{-1} \mathrm{~d}^{-1}$ ) were not fully overlapped with those of surface blooms (Figs. 31 and $8 c)$. Cui et al. (2019) suggested that the patchy distribution of bottom hypoxia was closely associated with the river plume front which traps organic particles (Hetland and DiMarco, 2008), accelerating their settlement and deposition in the overlapping zones between the river plume and shelf salt wedge (Zhang and Li, 2010) to fuel the high OCR there. In fact, only the west hypoxic centre was located beneath the surface bloom from leg 2 to leg 3 (Figs. $3 \mathrm{j}-1$ and $4 \mathrm{~g}-\mathrm{i}$ ). $\mathrm{Lu}$ et al. (2018) proposed another explanation that small detritus of external sources could be accumulated and remineralized in the bottom flow convergence zone as regulated by highly variable coastline and bottom topography. Our observed hypoxic zones generally coincided with the modelled strong convergence zones (Lu et al., 2018; Li et al., 2020), imply- 

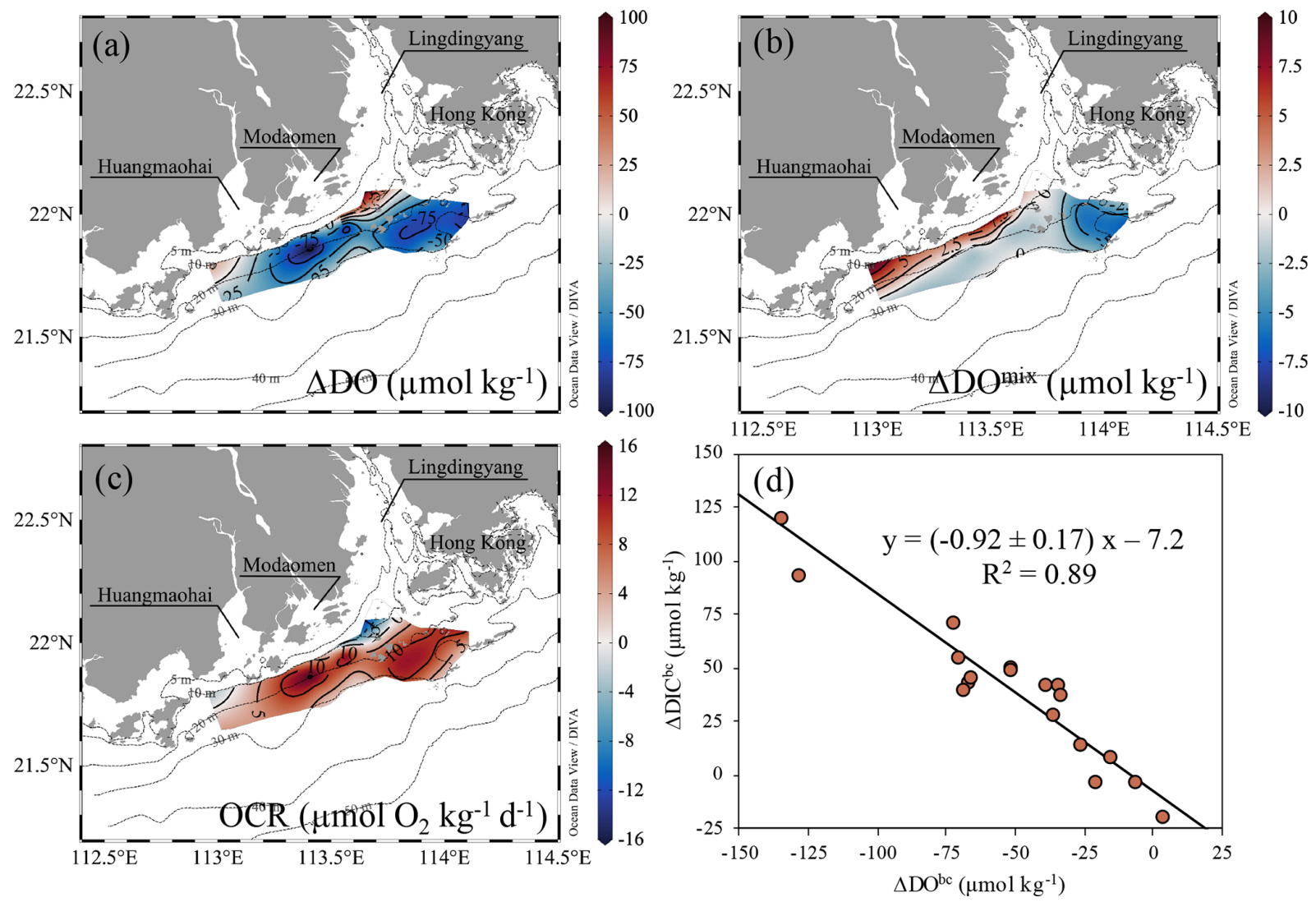

Figure 8. Distributions of (a) total DO changes $\left(\Delta \mathrm{DO}, \mu \mathrm{mol} \mathrm{kg}{ }^{-1}\right)$, (b) mixing-induced DO changes $\left(\Delta \mathrm{DO} \mathrm{mix}^{\mathrm{mix}}, \mu \mathrm{mol} \mathrm{kg}{ }^{-1}\right)$ and $(\mathbf{c})$ the biochemical-induced oxygen consumption rate (OCR, $\mu$ mol $\mathrm{O}_{2} \mathrm{~kg}^{-1} \mathrm{~d}^{-1}$ ) between leg 3 and leg 2 on the inner NSCS shelf off the PRE. (d) The biochemical-induced changes in DIC $\left(\Delta \mathrm{DIC}^{\mathrm{bc}}, \mu \mathrm{mol} \mathrm{kg}{ }^{-1}\right)$ vs. DO $\left(\Delta \mathrm{DO}^{\mathrm{bc}}, \mu \mathrm{mol} \mathrm{kg}{ }^{-1}\right)$ in bottom waters with depths $>10 \mathrm{~m}$ from leg 2 to leg 3 . The black line denotes the slope of $\Delta \mathrm{DIC}^{\mathrm{bc}}$ plotted against $\Delta \mathrm{DO}^{\mathrm{bc}}$ derived from the Model II regression.

ing sufficient organic matter supply fuelled the high OCR to restore hypoxia in bottom waters.

Our estimated OCR is comparable in magnitude to the community/bacterial respiration rate from previous studies in this study area $\left(9.6 \mu \mathrm{molO}_{2} \mathrm{~kg}^{-1} \mathrm{~d}^{-1}\right.$; Su et al., 2017; 7.9 to $19.0 \mu \mathrm{mol} \mathrm{O} \mathrm{kg}^{-1} \mathrm{~d}^{-1}$; Cui et al., 2019; $16.8 \pm 8.9 \mu \mathrm{mol} \mathrm{O} \mathrm{kg}^{-1} \mathrm{~d}^{-1}$; Li et al., 2019) and within the range in other estuaries and coastal systems (Dortch et al., 1994; Robinson, 2008), despite a lower limit due to a potential overestimation of the actual time if significant oxygen consumption started later than our observations during the first half of leg 2 and an assumed negligible oxygen flux supplied from the surface by diffusion. From leg 2 to leg 3, the vertical oxygen diffusion flux was $\sim 0.18 \mathrm{~g} \mathrm{~m}^{-2} \mathrm{~d}^{-1}$, amounting to a supply of $\sim 0.6-1.1 \mu \mathrm{mol} \mathrm{O}_{2} \mathrm{~kg}^{-1} \mathrm{~d}^{-1}$ to the bottom waters with a thickness of 5-10 $\mathrm{m}$. The exclusion of this vertical oxygen diffusion flux in our estimates therefore might underestimate the OCR by $\sim 6 \%$ on average. We also assumed that the OCR was uniform in the subsurface waters several metres above the seabed, because we collected samples at three depth layers during leg 2 and leg 3, with usually only one layer below the pycnocline for most stations.
For stations with the middle layer also below the pycnocline, such as station F304 during leg 3, the profile of DO concentrations showed almost constant values below the pycnocline (Fig. 7k). Sediment oxygen demand might be significant near the seabed or in its overlying water column in shallow waters (Kemp et al., 1992; Zhang and Li, 2010). However, our sampling at the bottom layer was $4-6 \mathrm{~m}$ above the seabed, and the water depth of the hypoxic zones was nearly $20 \mathrm{~m}$ (Fig. 4). In such sampling areas, Cui et al. (2019) found that oxygen losses by sediment oxygen demand (i.e. benthic respiration) were much smaller than the bacterial respiration in the water column based on both incubation experiments and oxygen budget analysis. We thus assumed the sediment oxygen demand was negligible and the microbial respiration in the water column dominated the estimated OCR.

However, the estimated OCR here differs in implications from that derived from the steady-state budget analysis in which the oxygen consumption was completely offset by the physical transport of oxygen (Zhang and Li, 2010; Cui et al., 2019). In our estimates, the OCR was derived during the hypoxia formation in which the in situ DO concentrations decreased over time (i.e. in a non-steady-state system) as oxy- 
gen sinks exceed sources. To shift from such a non-steadystate system towards a balance between oxygen consumption and replenishment for the maintenance of hypoxia, the OCR might decrease or the physical-induced oxygen supply increases. Kalvelage et al. (2015) found that aerobic respiration rates decreased with decreasing in situ DO concentrations, i.e. from the upper boundary of oxygen minimum zone (OMZ) towards the OMZ core off Peru. The oxygen enriched incubation of unfiltered water samples revealed that the OCR changed little when the in situ DO concentration was higher than $\sim 90 \mu \mathrm{mol} \mathrm{kg}^{-1}$ but also decreased when the in situ DO concentration decreased to $\sim 30 \mu \mathrm{mol} \mathrm{kg}^{-1}$ (He et al., 2014). Despite the bottom DO concentrations of $\sim 180 \mu \mathrm{mol} \mathrm{kg}-1$ at station F303 during the time-series observations, DO declined at a rate of $\sim 9 \mu \mathrm{mol} \mathrm{O} \mathrm{kg}^{-1} \mathrm{~d}^{-1}$ from 20-22 July, when the winds remained strong, and the OCR decreased to $\sim 5.5 \mu \mathrm{mol} \mathrm{O} \mathrm{kg}^{-1} \mathrm{~d}^{-1}$ from leg 2 (DO $\sim 164 \mu \mathrm{mol} \mathrm{kg}{ }^{-1}$ ) to leg 3 (DO $\sim 127 \mu \mathrm{mol} \mathrm{kg}^{-1}$ ) (from 22-29 July) (Fig. S3). The OCR declined likely as inhibited by the reduced supply of labile organic matter (Yuan et al., 2010) - the strong blooms shifted offshore with the river plume, and the Chl $a$ concentrations over the hypoxic zone also decreased from leg 2 to leg 3 (Fig. 3k, l). If we considered the shoreward intrusion of deep shelf waters following up the hypoxia development instead of contributing to lowering the initial DO level, their intrusion onto the inner shelf supplied oxygen to the oxygen-depleted waters, such as the cold, saline subsurface waters occupied the bottom layer covering the hypoxic zone on the inner shelf during leg 1 (Fig. $4 \mathrm{a}, \mathrm{g}$ ). As density stratification limited the vertical diffusivity of oxygen from the upper layer, bottom hypoxia was therefore progressively formed and maintained until the decreasing OCR almost achieved equilibrium with the oxygen supply from the lateral advection.

\subsubsection{Hypoxia formation timescale}

The above-estimated OCR and the contribution of shoreward-intruded deep shelf waters made it possible to roughly estimate the hypoxia formation timescale, i.e. the time that the DO level in a known volume of water takes to decrease below the hypoxia threshold from an assumed initial DO concentration (Fennel and Testa, 2019). In this study, for the reinstatement of hypoxia after the typhoon, the initial DO level in subsurface waters could be taken as $\sim 180 \mu \mathrm{mol} \mathrm{kg}{ }^{-1}$, which varied within $\pm 5 \mu \mathrm{mol} \mathrm{kg}{ }^{-1}$ throughout the time-series observations (Fig. 5c). Considering the OCR for the hypoxic zone was at most $\sim 20 \mu \mathrm{mol} \mathrm{O}_{2} \mathrm{~kg}^{-1} \mathrm{~d}^{-1}$ and the negligible contribution of lateral advection to oxygen loss off the Modaomen subestuary (Fig. 4), it took nearly $6 \mathrm{~d}$ for the drawdown of DO to reach concentrations of $\sim 63 \mu \mathrm{mol} \mathrm{kg}{ }^{-1}$ within a limited area. Scaling to a larger area, it would instead take $8-12 \mathrm{~d}$ if we choose the average OCR of the oxygen-deficit zone, i.e. $\sim 15 \pm 5 \mu \mathrm{mol} \mathrm{O} \mathrm{kg}^{-1} \mathrm{~d}^{-1}$ (Fig. 8c). These estimates of hypoxia formation timescales are shorter than the bottom water residence time ( $>15 \mathrm{~d}$, Li et al., 2020), which favoured the hypoxia formation to the west off the PRE (Su et al., 2017; Zhao et al., 2020).

For a more common scenario of hypoxia formation starting from late spring, we assumed that the shoreward-intruded oxygen-deficient offshore subsurface waters almost occupied the bottom layer on the inner shelf instead of the welloxygenated offshore surface waters, as during leg 1 (Fig. 4a, d). Based on the above estimates that the shoreward-intruded subsurface waters totally reduced the initial DO level by $8.6 \pm 1.7 \%$ of the oxygen decline for hypoxia formation, the initial DO level was lowered by $\sim 11 \mu \mathrm{mol} \mathrm{kg}^{-1}$ to be $\sim 183 \mu \mathrm{mol} \mathrm{kg}{ }^{-1}$ before biochemical oxygen consumption. The hypoxia hotspot will then first occur $\sim 6 \mathrm{~d}$ after its initiation on the inner NSCS shelf off the PRE and extend to a larger hypoxic zone within the water residence time of $>15 \mathrm{~d}$ (Lu et al., 2018; Li et al., 2020). This result is larger than that estimated by Fennel and Testa (2019) - $4 \mathrm{~d}$ - using the modelled OCR of $\sim 34 \mu \mathrm{mol} \mathrm{O} \mathrm{kg}^{-1} \mathrm{~d}^{-1}$ in the water column with a sediment oxygen demand of $\sim 2.1 \mathrm{~g} \mathrm{~m}^{-2} \mathrm{~d}^{-1}$, which were only applicable to the hypoxia formation in the Lingdingyang sub-estuary with shallower waters $(\sim 5 \mathrm{~m})$ (Zhang and $\mathrm{Li}, 2010$ ). This result is still at the lower end of the hypoxia formation timescale in large river-dominated shelves globally (e.g. East China Sea off the Changjiang estuary, Northern Gulf of Mexico and northwestern Black Sea), which varies from 8 to $89 \mathrm{~d}$ for hypoxia to develop once initiated (Fennel and Testa, 2019). This short hypoxia formation timescale likely owes to a high OCR in relatively warm subsurface waters fuelled by abundant labile organic matter ( $\mathrm{Su}$ et al., 2017; Zhao et al., 2020).

\subsection{Imprint of tropical cyclones on the evolution of coastal hypoxia}

Tropical cyclones dramatically alter the physical stability of the water column and attenuate or even disrupt hypoxic conditions at low and mid-latitudes, such as off the Changjiang Estuary (Ni et al., 2016; Zhang et al., 2020) and the PRE (Su et al., 2017; Huang et al., 2019), in Chesapeake Bay (Testa and Kemp, 2014; Testa et al., 2017), and in the northern Gulf of Mexico (Wang and Justić, 2009; Feng et al., 2012). These intense, episodic storms thus strongly impact the duration and intensity of oxygen depletion in coastal bottom waters (Rabalais et al., 2009; Wang et al., 2017a; Zhang et al., 2020), driving the seasonal hypoxia to be intermittent. As shown in Fig. 1, at least four named tropical cyclones impacted the study area from May to August in 2018, most of which shifted the wind direction from prevailing southwesterly to easterly or southeasterly and increased the wind speed up to over $9 \mathrm{~m} \mathrm{~s}^{-1}$, being able to destroy water column stratification and interrupt hypoxia formation (Geng et al., 2019). This was not an exception, as annually there were approximately six tropical cyclones travelling across the NSCS from 
May to September, when seasonal hypoxia develops (Qian et al., 2018; Wang et al., 2018), during the period from 19752019 (Fig. 9a). On average, five out of the six tropical cyclones on an annual basis had the maximum wind speeds exceeding $9 \mathrm{~m} \mathrm{~s}^{-1}$, which could easily destroy the stability of the water column and replenish oxygen into the bottom waters. Indeed, when tropical cyclones impacted the NSCS over the last 4 decades, the local maximum wind speeds typically reached over $9 \mathrm{~m} \mathrm{~s}^{-1}$ and often were larger than $15 \mathrm{~m} \mathrm{~s}^{-1}$ (Fig. 9b); the local wind direction was inclined to be from the east, accounting for $56.2 \%$ in frequency, followed by the north $(19.8 \%)$ and the west $(16.0 \%)$ (Fig. 9d). The longlasting easterly winds (Fig. 9e) were more likely to confine the river plume to the coast (Xu et al., 2019) and even force the riverine freshwater to subduct down to the depth (Fig. S2), strengthening the reaeration of the oxygen-poor bottom waters (Wang et al., 2017b, 2018; Huang et al., 2019). We also found that the time interval between two successive tropical cyclones was mostly less than $15 \mathrm{~d}$, especially from July to September (Fig. 9c), close to the timescale for hypoxia formation. The frequency of the time interval $<15 \mathrm{~d}$ showed a decreasing trend over 1975-2019 (Fig. 9c). Specifically, it averaged $4.1 \mathrm{yr}^{-1}$ before the year of 2000 in contrast to $2.8 \mathrm{yr}^{-1}$ after 2000 . This might partly explain why less hypoxia was formed and even observed before the year of 2000 (Yin et al., 2004; Rabouille et al., 2008). Therefore, frequent disturbance by tropical cyclones is one of the vital controls on the intermittent hypoxia in low-latitude river-dominated ocean margins.

Although strong winds constrain the development of hypoxia, tropical cyclones potentially promote intensive oxygen depletion after the transient dissipation of hypoxia (Rabalais et al., 2009). Heavy precipitation delivered by storms usually increases riverine freshwater loading to the coastal ocean (Zhou et al., 2012), resulting in intensified stratification when winds weaken (Wilson et al., 2008; Su et al., 2017). Indeed, heavy precipitation happened in the Pearl River Delta region after the landing of typhoon Son-Tinh, leading to a wide spreading of the river plume with lower salinity $(<15)$ than that during leg 1 and the intensification of stratification (Fig. 6), even though the river discharge of the PRE did not increase significantly (Li et al., 2021). Enhanced vertical mixing and/or freshwater discharge supplied large amounts of nutrients to the surface layer to fuel phytoplankton blooms following large storms (Zhao et al., 2009; Ni et al., 2016; Wang et al., 2017a), as shown in Fig. 3, such that strong blooms occurred in the surface plume along the coast with much higher Chl $a$ concentrations during leg 2 than during leg 1 . The fresh autochthonous organic matter, together with the resuspended sedimentary organic carbon, provides sufficient substrates for microbial respiration in a re-stratified water column, leading to renewed or even exacerbated bottom water oxygen depletion (Zhou et al., 2012; Song et al., 2020). Along the east coast of North America, lowered DO concentrations were observed after storms (Paerl et al., 2000;
Table 2. Summary of average frequency of tropical cyclones in each decade from 1950-2019. TD, TS, STS, TY and STY represent tropical depressions (the maximum wind speed near the centre is between $10.8-17.1 \mathrm{~m} \mathrm{~s}^{-1}$ over its lifetime), tropical storms (17.2-24.4 $\left.\mathrm{m} \mathrm{s}^{-1}\right)$, strong tropical storms $\left(24.5-32.6 \mathrm{~m} \mathrm{~s}^{-1}\right)$, typhoons $\left(32.7-41.4 \mathrm{~m} \mathrm{~s}^{-1}\right)$ and strong typhoons $\left(41.5-50.9 \mathrm{~m} \mathrm{~s}^{-1}\right)$, respectively.

\begin{tabular}{lrrrrrr}
\hline Years & TD & TS & STS & TY & STY & Sum \\
\hline $1950-1959$ & 3.5 & 1.1 & 1.2 & 1.1 & 1.5 & 8.4 \\
$1960-1969$ & 1.7 & 0.6 & 1.5 & 2.1 & 2.7 & 8.6 \\
$1970-1979$ & 1.8 & 0.7 & 2.1 & 2.1 & 1.2 & 7.9 \\
$1980-1989$ & 1.5 & 0.7 & 2.5 & 1.3 & 1.3 & 7.3 \\
$1990-1999$ & 0.7 & 1.2 & 1.8 & 2.0 & 1.1 & 6.8 \\
$2000-2009$ & 0.9 & 1.4 & 1.5 & 1.5 & 0.8 & 6.1 \\
$2010-2019$ & 0.6 & 1.8 & 1.4 & 0.4 & 1.5 & 5.7 \\
\hline
\end{tabular}

Tomasko et al., 2006). Hypoxia was re-established across a larger area when Hurricane Katrina crossed the southeast Louisiana coast (Rabalais et al., 2009). Off the PRE, we also found that hypoxia reoccurred in the wake of a more extensive freshwater plume and enhanced eutrophication after the passage of typhoon Son-Tinh (e.g. DO $\sim 45 \mu \mathrm{mol} \mathrm{kg}{ }^{-1}$ at stations F202 and F302). Whether it can develop into more severe hypoxia compared to that found initially during leg 1 depends on the net OCR and water column stability, up until the passage of the next storm, typhoon Bebinca (Fig. 1d).

In a changing climate, tropical cyclone features are believed to have a trend with higher intensity but lower frequency (Knutson et al., 2010; Chu et al., 2020). In the NSCS, the annual mean number of tropical cyclones in each decade decreased from 1950-2019, but the number of strong typhoons - the maximum wind speed near the centre is between $41.5-50.9 \mathrm{~m} \mathrm{~s}^{-1}$ over its lifetime - increased in the last decade (Table 2). The time interval between two successive tropical cyclones therefore increased by $2-3 \mathrm{~d}$ in the last 2 decades than prior to 2000 (Fig. 9c). The less-frequent disturbance in the stability of the water column by tropical cyclones and the elongated time interval between two successive tropical cyclones likely favour more persistent hypoxia. However, intensified tropical cyclones would destroy the hypoxia more completely. Despite stronger blooms after tropical cyclones as during leg 2 (Fig. 3k), the winds shifting back to prevailing southwest monsoon winds might drive the blooms offshore (Fig. 31), reducing the downward transport of fresh, labile organic matter to fuel intensive oxygen consumption in subsurface waters. In this sense, the development of coastal hypoxia depends on a trade-off between the intensity and frequency of tropical cyclones in a warmer ocean. 

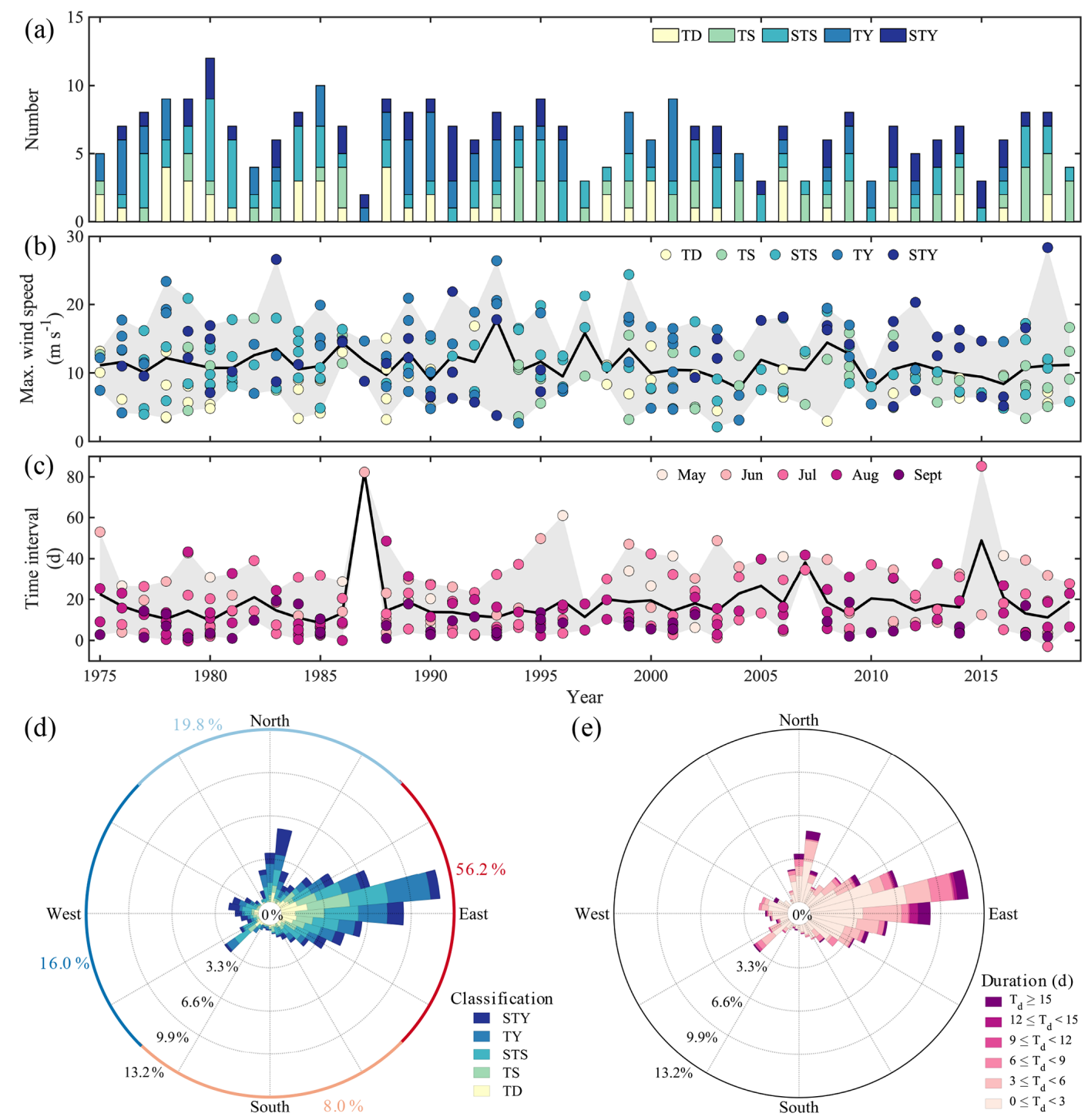

Figure 9. Statistics of tropical cyclones passing the northern South China Sea (NSCS) from May to September over 1975-2019. (a) Numbers of tropical cyclones. TD, TS, STS, TY and STY represent tropical depressions (the maximum wind speed near the centre is between 10.8$17.1 \mathrm{~m} \mathrm{~s}^{-1}$ over its lifetime), tropical storms (17.2-24.4 $\left.\mathrm{m} \mathrm{s}^{-1}\right)$, strong tropical storms $\left(24.5-32.6 \mathrm{~m} \mathrm{~s}^{-1}\right.$ ), typhoons (32.7-41.4 m s${ }^{-1}$ ) and strong typhoons (41.5-50.9 $\mathrm{m} \mathrm{s}^{-1}$ ), respectively. (b) The maximum wind speed of each tropical cyclone. The black line and grey shadow denote the annual average and range of the maximum wind speeds, respectively. (c) The time interval between two successive tropical cyclones. The black line and grey shadow denote the annual average and range of the time intervals, respectively. The negative time interval indicates an overlap in time of two successive tropical cyclones. (d) The wind rose of the intensity of tropical cyclones. (e) The wind rose of the duration of tropical cyclones. The wind speed in (b) and wind direction in (d) and (e) were recorded at Waglan Island (Fig. 1b).

\section{Conclusions}

We have demonstrated the evolution of intermittent hypoxia in summertime as disturbed by the typhoon passage on the inner NSCS shelf off the PRE and examined the controls on maintenance, destruction and reinstatement of hypoxia in this dynamic river-dominated marginal system. Eutrophication-induced hypoxia off the PRE was exacerbated with an enlarged area of $\sim 660 \mathrm{~km}^{2}$ and the lowest ever recorded regional DO concentration of $3.5 \mu \mathrm{mol} \mathrm{kg}-1$ $\left(\sim 0.1 \mathrm{mg} \mathrm{L}^{-1}\right)$. This area of hypoxia was likely underestimated due to spring-neap tidal oscillations, which has recently been demonstrated by a numerical model ( $\mathrm{Li}$ et al., 2020). Freshwater inputs suppressed wind-driven turbulent mixing and stabilized the water column, restricting the ventilation of the subsurface water and facilitating the formation and maintenance of hypoxia. We estimated for the first time the upwelling-induced oxygen decline and in situ OCR over the destruction and reinstatement of hypoxia, which took place on a timescale of 6-12 d. This in situ OCR could 
help constrain the source and sink terms for modelling oxygen dynamics in subtropical coastal waters. As the hypoxia timescale is shorter than water residence time but comparable with the disturbance of hypoxia from frequent tropical cyclones or high-wind events throughout the summer season, it could largely explain the intermittent nature of hypoxia off the PRE. Comparing with the hypoxia off large river systems at higher latitudes, tropical cyclones greatly influence the evolution of coastal hypoxia in tropical/subtropical regions. Nevertheless, how the changes in intensity and frequency of tropical cyclones would impact the development of coastal hypoxia in a warmer ocean clearly warrants further studies with carefully designed long-term observations and coupled physical-biogeochemical modelling.

Data availability. Data for temperature, salinity, DO and Chl $a$ are available at the National Earth System Science Data Centre, National Science and Technology Infrastructure of China (http://www.geodata.cn), and can be accessed through https://doi.org/10.12041/geodata.30199559780656.ver1.db

or https://dspace.xmu.edu.cn/handle/2288/178206 (last access: 2 February 2021) (Zhao et al., 2021). The wind speeds and directions at Waglan Island from May to August 2018 were obtained from Hong Kong Observatory (https://www.hko.gov.hk/en/cis/climat.htm, last access: 2 July 2020). The tidal heights at the Dawanshan gauge station near station F303 from May to August 2018 were downloaded from the following website (http://www.chinaports.com/en/tidal/, last access: 19 June 2020). Information from the tropical cyclone database (1949-2019) was obtained from the China Meteorological Administration (http://tcdata.typhoon.org.cn/, last access: 7 January 2020, Ying et al., 2014; Lu et al., 2021).

Supplement. The supplement related to this article is available online at: https://doi.org/10.5194/bg-18-2755-2021-supplement.

Author contributions. $\mathrm{YZ}$ and $\mathrm{MD}$ are major contributors to the study's conception, data analysis and drafting of the paper. KU contributed the sample collection and measurements of DO data. ZL contributed substantially to sample collection and data analysis of physical forcing. HL provided Chl $a$ data, and JG provided CTD data. YL, JL, and FM also contributed significantly to cruise design, sample collection and/or data acquisition.

Competing interests. The authors declare that they have no conflict of interest.

Acknowledgements. We thank Xue Song, Zhiqiang Liu, Dou Li, Zhongya Cai, Zhirong Xu, and Xuechao Wang for their assistance with sample collection; Liguo Guo, Shilei Jin, and Weizhen Jiang for assisting with sample measurements; Jianzhong Su for discussions and suggestions; and Richard Smith of Global Aquatic Re- search for assistance with English. We express our gratitude to two anonymous reviewers for their insightful comments and suggestions that helped substantially improve the clarity of the paper. The captain and the crew of R/V Haike 68 are acknowledged for their cooperation during the cruise.

Financial support. This research has been supported by the Hong Kong Research Grants Council (grant no. T21-602/16R), the Ministry of Science and Technology of China (grant no. 2015CB954000) and the China Scholarship Council (grant no. 201906310060).

Review statement. This paper was edited by Caroline P. Slomp and reviewed by two anonymous referees.

\section{References}

Allahdadi, M. N. and Li, C.: Numerical Experiment of Stratification Induced by Diurnal Solar Heating Over the Louisiana Shelf, in: Modeling Coastal Hypoxia: Numerical Simulations of Patterns, Controls and Effects of Dissolved Oxygen Dynamics, edited by: Justic, D., Rose, K. A., Hetland, R. D., and Fennel, K., Springer International Publishing, Cham, chap. 1, 1-22, https://doi.org/10.1007/978-3-319-54571-4_1, 2017.

Benson, B. B. and Krause Jr., D.: The concentration and isotopic fractionation of oxygen dissolved in freshwater and seawater in equilibrium with the atmosphere1, Limnol. Oceanogr., 29, 620632, https://doi.org/10.4319/lo.1984.29.3.0620, 1984.

Bianchi, T. S., Dimarco, S. F., Cowan, J. H., Hetland, R. D., Chapman, P., Day, J. W., and Allison, M. A.: The science of hypoxia in the northern Gulf of Mexico: A review, Sci. Total Environ., 408, 1471-1484, https://doi.org/10.1016/j.scitotenv.2009.11.047, 2010.

Breitburg, D., Levin, L. A., Oschlies, A., Grégoire, M., Chavez, F. P., Conley, D. J., Garçon, V., Gilbert, D., Gutiérrez, D., Isensee, K., Jacinto, G. S., Limburg, K. E., Montes, I., Naqvi, S. W. A., Pitcher, G. C., Rabalais, N. N., Roman, M. R., Rose, K. A., Seibel, B. A., Telszewski, M., Yasuhara, M., and Zhang, J.: Declining oxygen in the global ocean and coastal waters, Science, 359, eaam7240, https://doi.org/10.1126/science.aam7240, 2018.

Cai, W.-J., Dai, M. H., Wang, Y. C., Zhai, W. D., Huang, T., Chen, S. T., Zhang, F., Chen, Z. Z., and Wang, Z. H.: The biogeochemistry of inorganic carbon and nutrients in the Pearl River estuary and the adjacent Northern South China Sea, Cont. Shelf Res., 24, 1301-1319, https://doi.org/10.1016/j.csr.2004.04.005, 2004.

Cai, W.-J., Hu, X., Huang, W.-J., Jiang, L.-Q., Wang, Y., Peng, T.H., and Zhang, X.: Alkalinity distribution in the western North Atlantic Ocean margins, J. Geophys. Res.-Ocean., 115, C08014, https://doi.org/10.1029/2009JC005482, 2010.

Cao, Z. M., Dai, M. H., Zheng, N., Wang, D. L., Li, Q., Zhai, W. D., Meng, F. F., and Gan, J. P.: Dynamics of the carbonate system in a large continental shelf system under the influence of both a river plume and coastal upwelling, J. Geophys. Res.-Biogeo., 116, G02010, https://doi.org/10.1029/2010jg001596, 2011.

Chen, X., Shen, Z., Li, Y., and Yang, Y.: Physical controls of hypoxia in waters adjacent to the Yangtze Estuary: A 
numerical modeling study, Mar. Pollut. Bull., 97, 349-364, https://doi.org/10.1016/j.marpolbul.2015.05.067, 2015.

Chen, Z., Gong, W., Cai, H., Chen, Y., and Zhang, H.: Dispersal of the Pearl River plume over continental shelf in summer, Estuarine, Coast. Shelf Sci., 194, 252-262, https://doi.org/10.1016/j.ecss.2017.06.025, 2017a.

Chen, Z., Pan, J., Jiang, Y., and Lin, H.: Far-reaching transport of Pearl River plume water by upwelling jet in the northeastern South China Sea, J. Mar. Syst., 173, 60-69, https://doi.org/10.1016/j.jmarsys.2017.04.008, 2017 b.

Chu, J.-E., Lee, S.-S., Timmermann, A., Wengel, C., Stuecker, M. F., and Yamaguchi, R.: Reduced tropical cyclone densities and ocean effects due to anthropogenic greenhouse warming, Sci. Adv., 6, eabd5109, https://doi.org/10.1126/sciadv.abd5109, 2020.

Cui, Y. S., Wu, J. X., Ren, J., and Xu, J.: Physical dynamics structures and oxygen budget of summer hypoxia in the Pearl River Estuary, Limnol. Oceanogr., 64, 131-148, https://doi.org/10.1002/lno.11025, 2019.

Dai, M., Gan, J., Han, A., Kung, H., and Yin, Z.: Physical dynamics and biogeochemistry of the Pearl River plume, in: Biogeochemical Dynamics at Major River-Coastal Interfaces: Linkages with Global Change, edited by: Bianchi, T. S., Allison, M., and Cai, W.-J., Cambridge University Press, Cambridge, 321-352, 2014.

Diaz, R. J. and Rosenberg, R.: Spreading Dead Zones and Consequences for Marine Ecosystems, Science, 321, 926, https://doi.org/10.1126/science.1156401, 2008.

Dortch, Q., Rabalais, N. N., Turner, R. E., and Rowe, G. T.: Respiration rates and hypoxia on the Louisiana shelf, Estuaries, 17, 862-872, https://doi.org/10.2307/1352754, 1994.

Feng, Y., Dimarco, S. F., and Jackson, G. A.: Relative role of wind forcing and riverine nutrient input on the extent of hypoxia in the northern Gulf of Mexico, Geophys. Res. Lett., 39, L09601, https://doi.org/10.1029/2012GL051192, 2012.

Fennel, K. and Testa, J. M.: Biogeochemical Controls on Coastal Hypoxia, Ann. Rev. Mar. Sci., 11, 105-130, https://doi.org/10.1146/annurev-marine-010318-095138, 2019.

Gan, J. P., Cheung, A., Guo, X., and Li, L.: Intensified upwelling over a widened shelf in the northeastern South China Sea, J. Geophys. Res.-Ocean., 114, C09019, https://doi.org/10.1029/2007JC004660, 2009a.

Gan, J. P., Li, L., Wang, D. X., and Guo, X. G.: Interaction of a river plume with coastal upwelling in the northeastern South China Sea, Cont. Shelf Res., 29, 728-740, https://doi.org/10.1016/j.csr.2008.12.002, 2009b.

Geng, B. X., Xiu, P., Shu, C., Zhang, W. Z., Chai, F., Li, S. Y., and Wang, D. X.: Evaluating the Roles of Wind- and Buoyancy FluxInduced Mixing on Phytoplankton Dynamics in the Northern and Central South China Sea, J. Geophys. Res.-Ocean., 124, 680702, https://doi.org/10.1029/2018jc014170, 2019.

Gilbert, D., Rabalais, N. N., Díaz, R. J., and Zhang, J.: Evidence for greater oxygen decline rates in the coastal ocean than in the open ocean, Biogeosciences, 7, 2283-2296, https://doi.org/10.5194/bg-7-2283-2010, 2010.

Grantham, B. A., Chan, F., Nielsen, K. J., Fox, D. S., Barth, J. A., Huyer, A., Lubchenco, J., and Menge, B. A.: Upwellingdriven nearshore hypoxia signals ecosystem and oceanographic changes in the northeast Pacific, Nature, 429, 749-754, https://doi.org/10.1038/nature02605, 2004.
Guo, X. H. and Wong, G. T. F.: Carbonate chemistry in the Northern South China Sea Shelf-sea in June 2010, Deep-Sea Res. Pt. II, 117, 119-130, https://doi.org/10.1016/j.dsr2.2015.02.024, 2015.

Guo, X. H., Cai, W. J., Zhai, W. D., Dai, M. H., Wang, Y. C., and Chen, B. S.: Seasonal variations in the inorganic carbon system in the Pearl River (Zhujiang) estuary, Cont. Shelf Res., 28, 14241434, https://doi.org/10.1016/j.csr.2007.07.011, 2008.

He, B. Y., Dai, M. H., Zhai, W. D., Guo, X. H., and Wang, L. F.: Hypoxia in the upper reaches of the Pearl River Estuary and its maintenance mechanisms: A synthesis based on multiple year observations during 2000-2008, Mar. Chem., 167, 13-24, https://doi.org/10.1016/j.marchem.2014.07.003, 2014.

Hetland, R. D. and Dimarco, S. F.: How does the character of oxygen demand control the structure of hypoxia on the Texas-Louisiana continental shelf?, J. Mar. Syst., 70, 49-62, https://doi.org/10.1016/j.jmarsys.2007.03.002, 2008.

Hu, X. P., Li, Q., Huang, W. J., Chen, B. S., Cai, W. J., Rabalais, N. N., and Turner, R. E.: Effects of eutrophication and benthic respiration on water column carbonate chemistry in a traditional hypoxic zone in the Northern Gulf of Mexico, Mar. Chem., 194, 33-42, https://doi.org/10.1016/j.marchem.2017.04.004, 2017.

Huang, J., Hu, J., Li, S., Wang, B., Xu, Y., Liang, B., and Liu, D.: Effects of Physical Forcing on Summertime Hypoxia and Oxygen Dynamics in the Pearl River Estuary, Water, 11, 2080, https://doi.org/10.3390/w11102080, 2019.

Kalvelage, T., Lavik, G., Jensen, M. M., Revsbech, N. P., Löscher, C., Schunck, H., Desai, D. K., Hauss, H., Kiko, R., Holtappels, M., Laroche, J., Schmitz, R. A., Graco, M. I., and Kuypers, M. M. M.: Aerobic Microbial Respiration In Oceanic Oxygen Minimum Zones, Plos One, 10, e0133526, https://doi.org/10.1371/journal.pone.0133526, 2015.

Kemp, W. M., Sampou, P. A., Garber, J., Tuttle, J., and Boynton, W. R.: Seasonal depletion of oxygen from bottom waters of Chesapeake Bay: roles of benthic and planktonic respiration and physical exchange processes, Mar. Ecol. Prog. Ser., 85, 137-152, 1992.

Knutson, T. R., Mcbride, J. L., Chan, J., Emanuel, K., Holland, G., Landsea, C., Held, I., Kossin, J. P., Srivastava, A. K., and Sugi, M.: Tropical cyclones and climate change, Nat. Geosci., 3, 157163, https://doi.org/10.1038/ngeo779, 2010.

Koweek, D. A., García-Sánchez, C., Brodrick, P. G., Gassett, P., and Caldeira, K.: Evaluating hypoxia alleviation through induced downwelling, Sci. Total Environ., 719, 137334, https://doi.org/10.1016/j.scitotenv.2020.137334, 2020.

Labasque, T., Chaumery, C., Aminot, A., and Kergoat, G.: Spectrophotometric Winkler determination of dissolved oxygen: reexamination of critical factors and reliability, Mar. Chem., 88, 53-60, https://doi.org/10.1016/j.marchem.2004.03.004, 2004.

Laurent, A. and Fennel, K.: Time-Evolving, Spatially Explicit Forecasts of the Northern Gulf of Mexico Hypoxic Zone, Environ. Sci. Technol., 53, 14449-14458, https://doi.org/10.1021/acs.est.9b05790, 2019.

Li, D., Gan, J., Hui, R., Liu, Z., Yu,L., Lu, Z., and Dai, M.: Vortex and Biogeochemical Dynamics for the Hypoxia Formation Within the Coastal Transition Zone off the Pearl River Estuary, J. Geophys. Res.-Ocean., 125, e2020JC016178, https://doi.org/10.1029/2020JC016178, 2020.

Li, D., Gan, J., Hui, C., Yu, L., Liu, Z., Lu, Z., Kao, S.J., and Dai, M.: Spatiotemporal Development and Dissipation 
of Hypoxia Induced by Variable Wind-Driven Shelf Circulation off the Pearl River Estuary: Observational and Modeling Studies, J. Geophys. Res.-Ocean., 126, e2020JC016700, https://doi.org/10.1029/2020JC016700, 2021.

Li, M., Lee, Y. J., Testa, J. M., Li, Y., Ni, W., Kemp, W. M., and Di Toro, D. M.: What drives interannual variability of hypoxia in Chesapeake Bay: Climate forcing versus nutrient loading?, Geophys. Res. Lett., 43, 2127-2134, https://doi.org/10.1002/2015GL067334, 2016.

Li, X. F., Xu, J., Shi, Z., and Li, R. H.: Response of Bacterial Metabolic Activity to the River Discharge in the Pearl River Estuary: Implication for $\mathrm{CO}_{2}$ Degassing Fluxes, Front. Microbiol., 10, 1026, https://doi.org/10.3389/fmicb.2019.01026, 2019.

Li, Y., Li, M., and Kemp, W. M.: A Budget Analysis of BottomWater Dissolved Oxygen in Chesapeake Bay, Estuar. Coast., 38, 2132-2148, https://doi.org/10.1007/s12237-014-9928-9, 2015.

Lu, Z. M. and Gan, J. P.: Controls of seasonal variability of phytoplankton blooms in the Pearl River Estuary, Deep-Sea Res. Pt. II, 117, 86-96, https://doi.org/10.1016/j.dsr2.2013.12.011, 2015.

Lu, Z. M., Gan, J. P., Dai, M. H., Liu, H. B., and Zhao, X. Z.: Joint Effects of Extrinsic Biophysical Fluxes and Intrinsic Hydrodynamics on the Formation of Hypoxia West off the Pearl River Estuary, J. Geophys. Res.-Ocean., 123, 6241-6259, https://doi.org/10.1029/2018jc014199, 2018.

Lu, X., Yu, H., Ying, M., Zhao, B., Zhang, S., Lin, L., Bai, L., and Wan, R.: Western North Pacific Tropical Cyclone Database Created by the China Meteorological Administration, Adv. Atmos. Sci., 38, 690-699, https://doi.org//10.1007/s00376-020-0211-7, 2021.

Maccready, P., Banas, N. S., Hickey, B. M., Dever, E. P., and Liu, Y.: A model study of tide- and wind-induced mixing in the Columbia River Estuary and plume, Cont. Shelf Res., 29, 278291, https://doi.org/10.1016/j.csr.2008.03.015, 2009.

Mendelsohn, R., Emanuel, K., Chonabayashi, S., and Bakkensen, L.: The impact of climate change on global tropical cyclone damage, Nat. Clim. Change, 2, 205-209, https://doi.org/10.1038/Nclimate1357, 2012.

Murphy, R. R., Kemp, W. M., and Ball, W. P.: Long-Term Trends in Chesapeake Bay Seasonal Hypoxia, Stratification, and Nutrient Loading, Estuar. Coast., 34, 1293-1309, https://doi.org/10.1007/s12237-011-9413-7, 2011.

Naqvi, S. W. A., Bange, H. W., Farías, L., Monteiro, P. M. S., Scranton, M. I., and Zhang, J.: Marine hypoxia/anoxia as a source of $\mathrm{CH}_{4}$ and $\mathrm{N}_{2} \mathrm{O}$, Biogeosciences, 7, 2159-2190, https://doi.org/10.5194/bg-7-2159-2010, 2010.

Ni, X., Huang, D., Zeng, D., Zhang, T., Li, H., and Chen, J.: The impact of wind mixing on the variation of bottom dissolved oxygen off the Changjiang Estuary during summer, J. Mar. Syst., 154, 122-130, https://doi.org/10.1016/j.jmarsys.2014.11.010, 2016.

Obenour, D. R., Michalak, A. M., Zhou, Y., and Scavia, D.: Quantifying the Impacts of Stratification and Nutrient Loading on Hypoxia in the Northern Gulf of Mexico, Environ. Sci. Technol., 46, 5489-5496, https://doi.org/10.1021/es204481a, 2012.

Paerl, H. W., Bales, J. D., Ausley, L. W., Buzzelli, C. P., Crowder, L. B., Eby, L. A., Go, M., Peierls, B. L., Richardson, T. L., and Ramus, J. S.: Hurricanes' hydrological, ecological effects linger in major U.S. estuary, Eos, Trans. Am. Geophys. Un., 81, 457462, https://doi.org/10.1029/00EO00338, 2000.
Pan, J. Y. and Gu, Y. Z.: Cruise observation and numerical modeling of turbulent mixing in the Pearl River estuary in summer, Cont. Shelf Res., 120, 122-138, https://doi.org/10.1016/j.csr.2016.03.019, 2016.

Pan, J. Y., Gu, Y. Z., and Wang, D. X.: Observations and numerical modeling of the Pearl River plume in summer season, J. Geophys. Res.-Ocean., 119, 2480-2500, https://doi.org/10.1002/2013jc009042, 2014.

Qian, W., Dai, M., Xu, M., Kao, S.-J., Du, C., Liu, J., Wang, H., Guo, L., and Wang, L.: Non-local drivers of the summer hypoxia in the East China Sea off the Changjiang Estuary, Estuarine, Coast. Shelf Sci., 198, 393-399, https://doi.org/10.1016/j.ecss.2016.08.032, 2017.

Qian, W., Gan, J. P., Liu, J. W., He, B. Y., Lu, Z. M., Guo, X. H., Wang, D. L., Guo, L. G., Huang, T., and Dai, M. H.: Current status of emerging hypoxia in a eutrophic estuary: The lower reach of the Pearl River Estuary, China, Estuar. Coast. Shelf S., 205, 58-67, https://doi.org/10.1016/j.ecss.2018.03.004, 2018.

Qiu, D., Zhong, Y., Chen, Y., Tan, Y., Song, X., and Huang, L.: Short-Term Phytoplankton Dynamics During Typhoon Season in and Near the Pearl River Estuary, South China Sea, J. Geophys. Res.-Biogeo., 124, 274-292, https://doi.org/10.1029/2018JG004672, 2019.

Qu, T., Du, Y., Gan, J., and Wang, D.: Mean seasonal cycle of isothermal depth in the South China Sea, J. Geophys. Res.Ocean., 112, C02020, https://doi.org/10.1029/2006JC003583, 2007.

Rabalais, N. N., Turner, R. E., Diaz, R. J., and Justic, D.: Global change and eutrophication of coastal waters, ICES J. Mar. Sci., 66, 1528-1537, https://doi.org/10.1093/icesjms/fsp047, 2009.

Rabalais, N. N., Cai, W. J., Carstensen, J., Conley, D. J., Fry, B., Hu, X. P., Quinones-Rivera, Z., Rosenberg, R., Slomp, C. P., Turner, R. E., Voss, M., Wissel, B., and Zhang, J.: Eutrophication-Driven Deoxygenation in the Coastal Ocean, Oceanography, 27, 172183, https://doi.org/10.5670/oceanog.2014.21, 2014.

Rabouille, C., Conley, D. J., Dai, M. H., Cai, W. J., Chen, C. T. A., Lansard, B., Green, R., Yin, K., Harrison, P. J., Dagg, M., and Mckee, B.: Comparison of hypoxia among four riverdominated ocean margins: The Changjiang (Yangtze), Mississippi, Pearl, and Rhône rivers, Cont. Shelf Res., 28, 1527-1537, https://doi.org/10.1016/j.csr.2008.01.020, 2008.

Robinson, C.: Heterotrophic Bacterial Respiration, in: Microbial Ecology of the Oceans, edited by: Kirchman, D. L., 299-334, https://doi.org/10.1002/9780470281840.ch9, 2008.

Schlitzer, R.: Ocean Data View, https://odv.awi.de (last access: 8 June 2020), 2018.

Song, G., Zhao, L., Chai, F., Liu, F., Li, M., and Xie, H.: Summertime Oxygen Depletion and Acidification in Bohai Sea, China, Front. Mar. Sci., 7, 252, https://doi.org/10.3389/fmars.2020.00252, 2020.

Su, J.: Overview of the South China Sea circulation and its influence on the coastal physical oceanography outside the Pearl River Estuary, Cont. Shelf Res., 24, 1745-1760, https://doi.org/10.1016/j.csr.2004.06.005, 2004.

Su, J. Z., Dai, M. H., He, B. Y., Wang, L. F., Gan, J. P., Guo, X. H., Zhao, H. D., and Yu, F. L.: Tracing the origin of the oxygenconsuming organic matter in the hypoxic zone in a large eutrophic estuary: the lower reach of the Pearl River Estuary, China, 
Biogeosciences, 14, 4085-4099, https://doi.org/10.5194/bg-144085-2017, 2017.

Tedford, E. W., Carpenter, J. R., Pawlowicz, R., Pieters, R., and Lawrence, G. A.: Observation and analysis of shear instability in the Fraser River estuary, J. Geophys. Res.-Ocean., 114, C11006, https://doi.org/10.1029/2009JC005313, 2009.

Testa, J. M. and Kemp, W. M.: Spatial and Temporal Patterns of Winter-Spring Oxygen Depletion in Chesapeake Bay Bottom Water, Estuar. Coast., 37, 1432-1448, https://doi.org/10.1007/s12237-014-9775-8, 2014.

Testa, J. M., Clark, J. B., Dennison, W. C., Donovan, E. C., Fisher, A. W., Ni, W., Parker, M., Scavia, D., Spitzer, S. E., Waldrop, A. M., Vargas, V. M. D., and Ziegler, G.: Ecological Forecasting and the Science of Hypoxia in Chesapeake Bay, Bioscience, 67, 614-626, https://doi.org/10.1093/biosci/bix048, 2017.

Tomasko, D. A., Anastasiou, C., and Kovach, C.: Dissolved oxygen dynamics in Charlotte Harbor and its contributing watershed, in response to hurricanes Charley, Frances, and Jeanne-Impacts and recovery, Estuar. Coast., 29, 932-938, https://doi.org/10.1007/BF02798653, 2006.

Vaquer-Sunyer, R. and Duarte, C. M.: Thresholds of hypoxia for marine biodiversity, P. Natl. Acad. Sci. USA, 105, 15452, https://doi.org/10.1073/pnas.0803833105, 2008.

Wang, B.: Hydromorphological mechanisms leading to hypoxia off the Changjiang estuary, Mar. Environ. Res., 67, 53-58, https://doi.org/10.1016/j.marenvres.2008.11.001, 2009.

Wang, B., Chen, J. F., Jin, H. Y., Li, H. L., Huang, D. J., and Cai, W. J.: Diatom bloom-derived bottom water hypoxia off the Changjiang estuary, with and without typhoon influence, Limnol. Oceanogr., 62, 1552-1569, https://doi.org/10.1002/lno.10517, $2017 \mathrm{a}$.

Wang, B., Hu, J. T., Li, S. Y., and Liu, D. H.: A numerical analysis of biogeochemical controls with physical modulation on hypoxia during summer in the Pearl River estuary, Biogeosciences, 14, 2979-2999, https://doi.org/10.5194/bg-14-2979-2017, 2017 b.

Wang, B., Hu, J. T., Li, S. Y., Yu, L. Q., and Huang, J.: Impacts of anthropogenic inputs on hypoxia and oxygen dynamics in the Pearl River estuary, Biogeosciences, 15, 6105-6125, https://doi.org/10.5194/bg-15-6105-2018, 2018.

Wang, D. X., Shu, Y. Q., Xue, H. J., Hu, J. Y., Chen, J., Zhuang, W., Zu, T. T., and Xu, J. D.: Relative contributions of local wind and topography to the coastal upwelling intensity in the northern South China Sea, J. Geophys. Res.-Ocean., 119, 2550-2567, https://doi.org/10.1002/2013jc009172, 2014.

Wang, L. and Justić, D.: A modeling study of the physical processes affecting the development of seasonal hypoxia over the inner Louisiana-Texas shelf: Circulation and stratification, Cont. Shelf Res., 29, 1464-1476, https://doi.org/10.1016/j.csr.2009.03.014, 2009.

Wei, X., Zhan, H. G., Ni, P. T., and Cai, S. Q.: A model study of the effects of river discharges and winds on hypoxia in summer in the Pearl River Estuary, Mar. Pollut. Bull., 113, 414-427, https://doi.org/10.1016/j.marpolbul.2016.10.042, 2016.

Welschmeyer, N. A.: Fluorometric analysis of chlorophyll a in the presence of chlorophyll $\mathrm{b}$ and pheopigments, Limnol. Oceanogr., 39, 1985-1992, https://doi.org/10.4319/lo.1994.39.8.1985, 1994.

Wilson, R. E., Swanson, R. L., and Crowley, H. A.: Perspectives on long-term variations in hypoxic conditions in west- ern Long Island Sound, J. Geophys. Res.-Ocean., 113, C12011, https://doi.org/10.1029/2007JC004693, 2008.

Wong, G. T. F., Ku, T.-L., Mulholland, M., Tseng, C.-M., and Wang, D.-P.: The SouthEast Asian Time-series Study (SEATS) and the biogeochemistry of the South China Sea-An overview, Deep-Sea Res. Pt. II, 54, 1434-1447, https://doi.org/10.1016/j.dsr2.2007.05.012, 2007.

Wong, L. A., Chen, J., Xue, H., Dong, L. X., Su, J. L., and Heinke, G.: A model study of the circulation in the Pearl River Estuary (PRE) and its adjacent coastal waters: 1. Simulations and comparison with observations, J. Geophys. Res.-Ocean., 108, 3156, https://doi.org/10.1029/2002jc001451, 2003.

$\mathrm{Xu}$, C., Xu, Y. J., Hu, J. T., Li, S. Y., and Wang, B.: A numerical analysis of the summertime Pearl River plume from 1999 to 2010: Dispersal patterns and intraseasonal variability, J. Mar. Syst., 192, 15-27, https://doi.org/10.1016/j.jmarsys.2018.12.010, 2019.

Yang, D., Yin, B., Sun, J., and Zhang, Y.: Numerical study on the origins and the forcing mechanism of the phosphate in upwelling areas off the coast of Zhejiang province, China in summer, J. Mar. Syst., 123/124, 1-18, https://doi.org/10.1016/j.jmarsys.2013.04.002, 2013.

Yin, K. D., Lin, Z. F., and Ke, Z. Y.: Temporal and spatial distribution of dissolved oxygen in the Pearl River Estuary and adjacent coastal waters, Cont. Shelf Res., 24, 1935-1948, https://doi.org/10.1016/j.csr.2004.06.017, 2004.

Ying, M., Zhang, W., Yu, H., Lu, X., Feng, J., Fan, Y., Zhu, Y., and Chen, D.: An Overview of the China Meteorological Administration Tropical Cyclone Database, J. Atmos. Ocean Tech., 31, 287-301, https://doi.org/10.1175/JTECH-D-12-00119.1, 2014.

Yu, L., Fennel, K., Laurent, A., Murrell, M. C., and Lehrter, J. C.: Numerical analysis of the primary processes controlling oxygen dynamics on the Louisiana shelf, Biogeosciences, 12, 20632076, https://doi.org/10.5194/bg-12-2063-2015, 2015.

Yu, L., Gan, J., Dai, M., Hui, C. R., Lu, Z., and Li, D.: Modeling the role of riverine organic matter in hypoxia formation within the coastal transition zone off the Pearl River Estuary, Limnol. Oceanogr., 66, 452-468, https://doi.org/10.1002/lno.11616, 2021.

Yuan, X., Yin, K., Harrison, P. J., Cai, W., He, L., and $\mathrm{Xu}$, J.: Bacterial production and respiration in subtropical Hong Kong waters: influence of the Pearl River discharge and sewage effluent, Aquat. Microb. Ecol., 58, 167-179, https://doi.org/10.3354/ame01346, 2010.

Zhang, H. and Li, S. Y.: Effects of physical and biochemical processes on the dissolved oxygen budget for the Pearl River Estuary during summer, J. Mar. Syst., 79, 65-88, https://doi.org/10.1016/j.jmarsys.2009.07.002, 2010.

Zhang, H., Fennel, K., Laurent, A., and Bian, C.: A numerical model study of the main factors contributing to hypoxia and its interannual and short-term variability in the East China Sea, Biogeosciences, 17, 5745-5761, https://doi.org/10.5194/bg-175745-2020, 2020.

Zhang, W., Wu, H., Hetland, R. D., and Zhu, Z.: On Mechanisms Controlling the Seasonal Hypoxia Hot Spots off the Changjiang River Estuary, J. Geophys. Res.-Ocean., 124, 86838700, https://doi.org/10.1029/2019jc015322, 2019.

Zhao, H., Tang, D. L., and Wang, D. X.: Phytoplankton blooms near the Pearl River Estuary induced by 
Typhoon Nuri, J. Geophys. Res.-Ocean., 114, C12027, https://doi.org/10.1029/2009jc005384, 2009.

Zhao, Y., Liu, J., Uthaipan, K., Song, X., Xu, Y., He, B., Liu, H., Gan, J., and Dai, M.: Dynamics of inorganic carbon and $\mathrm{pH}$ in a large subtropical continental shelf system: Interaction between eutrophication, hypoxia, and ocean acidification, Limnol. Oceanogr., 65, 1359-1379, https://doi.org/10.1002/lno.11393, 2020.
Zhao, Y., Uthaipan, K., Lu, Z., Li, Y., Liu, J., Liu, H., Gan, J., Meng, F., and Dai, M.: The data set of dissolved oxygen concentrations in the South China Sea off the Pearl River Estuary in July 2018, GEODATA [Dataset], https://doi.org/10.12041/geodata.30199559780656.ver1.db, 2021.

Zhou, W., Yin, K., Harrison, P. J., and Lee, J. H. W.: The influence of late summer typhoons and high river discharge on water quality in Hong Kong waters, Estuar. Coast. Shelf Sci., 111, 35-47, https://doi.org/10.1016/j.ecss.2012.06.004, 2012. 